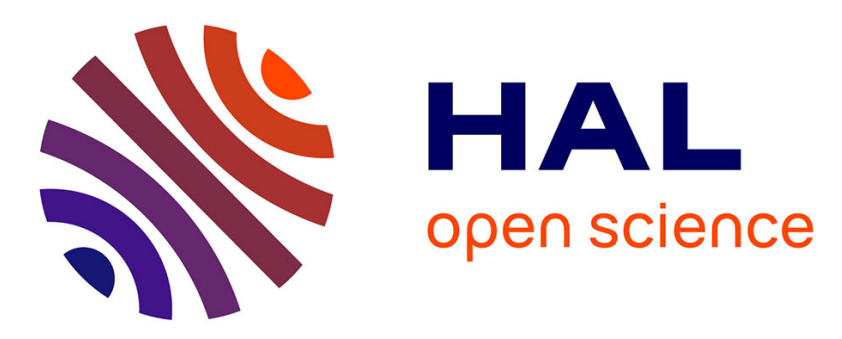

\title{
Stability and solubility of arsenopyrite, FeAsS, in crustal fluids.
}

Gleb S. Pokrovski, Sami Kara, Jacques Roux

\section{To cite this version:}

Gleb S. Pokrovski, Sami Kara, Jacques Roux. Stability and solubility of arsenopyrite, FeAsS, in crustal fluids.. Geochimica et Cosmochimica Acta, 2002, 66, pp.2361-2378. 10.1016/S0016-7037(02)00836-0 . hal-00076846

\section{HAL Id: hal-00076846 \\ https://hal-insu.archives-ouvertes.fr/hal-00076846}

Submitted on 3 Jun 2013

HAL is a multi-disciplinary open access archive for the deposit and dissemination of scientific research documents, whether they are published or not. The documents may come from teaching and research institutions in France or abroad, or from public or private research centers.
L'archive ouverte pluridisciplinaire HAL, est destinée au dépôt et à la diffusion de documents scientifiques de niveau recherche, publiés ou non, émanant des établissements d'enseignement et de recherche français ou étrangers, des laboratoires publics ou privés. 
PII S0016-7037(02)00836-0

\title{
Stability and solubility of arsenopyrite, FeAsS, in crustal fluids
}

\author{
Gleb S. Pokrovski,* SAmi Kara, and JacQues Roux, \\ Institut des Sciences de la Terre d'Orléans (ISTO), UMR 6133 of CNRS, 1A rue de la Férollerie, 45071 Orléans cedex 2, France
}

(Received August 23, 2001; accepted in revised form December 24, 2001)

\begin{abstract}
The stability and solubility of natural arsenopyrite (FeAsS) in pure water and moderately acid to slightly basic aqueous solutions buffered or not with $\mathrm{H}_{2}$ and/or $\mathrm{H}_{2} \mathrm{~S}$ were studied at temperatures from 300 to $450^{\circ} \mathrm{C}$ and pressures from 100 to 1000 bar. The solubilities of FeAsS in pure water and dilute $\mathrm{HCl} / \mathrm{NaOH}$ solutions without buffering are consistent with the formation of the $\mathrm{As}(\mathrm{OH})_{3}{ }^{\mathrm{O}}(\mathrm{aq})$ species and precipitation of magnetite. At more acid $\mathrm{pH}(\mathrm{pH} \leq 2)$, arsenopyrite dissolves either stoichiometrically or with formation of the As-FeAsS assemblage. In $\mathrm{H}_{2} \mathrm{~S}$-rich and $\mathrm{H}_{2}$-rich aqueous solutions, arsenopyrite dissolution results in the formation of pyrrhotite ( \pm pyrite) and iron arsenide(s), respectively, which form stable assemblages with arsenopyrite.

Arsenic concentrations measured in equilibrium with $\mathrm{FeAsS}$ in slightly acid to neutral aqueous solutions with $\mathrm{H}_{2}$ and $\mathrm{H}_{2} \mathrm{~S}$ fugacities buffered by the pyrite-pyrrhotite-magnetite assemblage are $0.0006 \pm 0.0002$, $0.0055 \pm 0.0010,0.07 \pm 0.01$, and $0.32 \pm 0.03 \mathrm{~mol} / \mathrm{kg} \mathrm{H}_{2} \mathrm{O}$ at $300^{\circ} \mathrm{C} / 400 \mathrm{bar}, 350^{\circ} \mathrm{C} / 500 \mathrm{bar}, 400^{\circ} \mathrm{C} / 500$ bar, and $450^{\circ} \mathrm{C} / 500$ bar, respectively. These values were combined with the available thermodynamic data on $\mathrm{As}(\mathrm{OH})_{3}{ }^{\circ}(\mathrm{aq})$ (Pokrovski et al., 1996) to derive the Gibbs free energy of FeAsS at each corresponding temperature and pressure. Extrapolation of these values to $25^{\circ} \mathrm{C}$ and $1 \mathrm{bar}$, using the available heat capacity and entropy data for FeAsS (Pashinkin et al., 1989), yields a value of $-141.6 \pm 6.0 \mathrm{~kJ} / \mathrm{mol}$ for the standard Gibbs free energy of formation of arsenopyrite. This value implies a higher stability of FeAsS in hydrothermal environments than was widely assumed.

Calculations carried out using the new thermodynamic properties of FeAsS demonstrate that this mineral controls As transport and deposition by high-temperature $\left(>\sim 300^{\circ} \mathrm{C}\right)$ crustal fluids during the formation of magmatic-hydrothermal $\mathrm{Sn}-\mathrm{W}-\mathrm{Cu}-(\mathrm{Au})$ deposits. The equilibrium between As-bearing pyrite and the fluid is likely to account for the As concentrations measured in modern high- and moderate-temperature $(150 \leq T \leq$ $350^{\circ} \mathrm{C}$ ) hydrothermal systems. Calculations indicate that the local dissolution of arsenopyrite creates more reducing conditions than in the bulk fluid, which is likely to be an effective mechanism for precipitating gold from hydrothermal solutions. This could be a possible explanation for the gold-arsenopyrite association commonly observed in many hydrothermal gold deposits. Copyright $₫ 2002$ Elsevier Science Ltd
\end{abstract}

\section{INTRODUCTION}

The motivation for this study is the improved understanding and quantification of the geochemistry of arsenic and associated elements during their transport by crustal fluids and the formation of hydrothermal ore deposits. Knowledge of the identity and thermodynamic properties of As aqueous complexes and solid phases is a key for predicting the behavior of As in a variety of environments such as hydrothermal and volcanic systems, toxic waste sites, and hydrometallurgical processes. Arsenic is transported in hydrothermal fluids mainly as As(III), forming hydroxide and sulfide complexes (Ballantine and Moore, 1988; Spycher and Reed, 1989a, 1989b; Pokrovski et al., 1996, and references therein). Thermodynamic analyses imply that As hydroxide complexes are likely to be the major species in most natural hydrothermal solutions, especially at temperatures above $150^{\circ} \mathrm{C}$ (Heinrich and Eadington, 1986; Akinfiev et al., 1992). Recently, it has been shown that $\mathrm{As}(\mathrm{OH})_{3}{ }^{\mathrm{O}}(\mathrm{aq})$ is the dominant $\mathrm{As}(\mathrm{III})$ species in aqueous hydrothermal fluids up to at least $300^{\circ} \mathrm{C}$ (Pokrovski et al., 1996; Gout et al., 1997). These results, combined with the corresponding thermodynamic properties of As oxides and sulfides, allowed the generation of a self-consistent set of thermody-

* Author to whom correspondence should be addressed (gleb@cnrsorleans.fr) namic data for the system $\mathrm{As}_{2} \mathrm{O}_{3}-\mathrm{As}_{2} \mathrm{~S}_{3}-\mathrm{H}_{2} \mathrm{O}$ at subcritical temperatures (Pokrovski et al., 1996). At temperatures higher than 250 to $300^{\circ} \mathrm{C}$, however, arsenic sulfides (orpiment and realgar) are extremely soluble, and the most common Asbearing mineral formed from near-critical and supercritical hydrothermal fluids is arsenopyrite (FeAsS). Unfortunately, the thermodynamic properties and stability of this mineral are poorly known. The aims of this paper are to determine the stability and solubility of arsenopyrite at conditions typical of its formation in natural hydrothermal environments and to apply these data to better understanding the behavior of As and associated elements $(\mathrm{Fe}, \mathrm{S}, \mathrm{Au})$ in crustal fluids.

Arsenopyrite is the ubiquitous As-bearing mineral in a variety of hydrothermal environments, from high-temperature magmatic-hydrothermal porphyry-style $\mathrm{Sn}-\mathrm{W}$ and $\mathrm{Cu}( \pm \mathrm{Au})$ deposits to mesothermal polymetallic $\mathrm{Cu}-\mathrm{Pb}-\mathrm{Zn}-\mathrm{Ag}$ and gold deposits. The formation conditions of arsenopyrite in these deposits correspond to a temperature range from $\sim 250$ to $500^{\circ} \mathrm{C}$ (Scott, 1983; Sharp et al., 1985; Heinrich and Eadington, 1986; Kerr et al., 1999; Audédat et al., 2000, and references therein). At lower temperatures $\left(<250\right.$ to $\left.300^{\circ} \mathrm{C}\right)$, arsenian pyrite is a common As-bearing phase in gold meso- and epithermal sulfide deposits and modern hydrothermal sources (Ballantine and Moore, 1988; Fleet et al., 1989, 1993; Mumin et al., 1994, and references therein), with maximum As contents up to 8 wt.\% (Fleet et al., 1989). Although different 
chemical states of As in pyrite and arsenopyrite have been proposed (Wu and Delbove, 1989; Johan et al., 1989; Fleet et al., 1993), recent spectroscopic measurements (Fleet et al., 1989; Simon et al., 1999) together with molecular orbital calculations (Tossel et al., 1981) and crystal structure refinements (Fuess et al., 1987) suggest a valence state -1 for As and, most likely, a solid solution between pyrite and arsenopyrite. The most interesting feature of these arsenian minerals is their close association with gold in meso- and epithermal deposits. Ample literature exists on gold-arsenopyrite and goldpyrite relationships and the chemical state of $\mathrm{Au}$ in these minerals. Many studies have revealed strong positive correlations between $\mathrm{Au}$ and As contents in pyrites from different meso- and epithermal $\mathrm{Au}$ deposits (e.g., Cathelineau et al., 1989; Wu and Delbove, 1989; Cook and Chryssoulis, 1990; Mao, 1991; Fleet et al., 1993). The presence of both chemically bound and native gold in arsenopyrite and As-pyrite has been demonstrated (Cabri et al., 1989, 2000; Fleet and Mumin, 1997; Genkin et al., 1998; Simon et al., 1999). The physical-chemical reasons for the $\mathrm{Au}-\mathrm{As}$ links and possible mechanisms of $\mathrm{Au}$ precipitation and incorporation in arsenopyrite are, however, poorly known, and the existing hypotheses remain often controversial (e.g., Cathelineau et al., 1989; Arehart et al., 1993; Fleet and Mumin, 1997; Maddox et al., 1998). Accurate knowledge of the thermodynamic properties and solubility of arsenopyrite in the ore-forming fluids is a step toward a quantitative understanding of the Au-As relationships.

Thermodynamic information on arsenopyrite and other (sulfo-)arsenides (FeAs, $\mathrm{FeAs}_{2}$, CoAsS, etc.) is, however, very scarce. Studies have attempted to characterize the phase equilibria in the dry system $\mathrm{Fe}-\mathrm{As}-\mathrm{S}$ at temperatures above $500^{\circ} \mathrm{C}$ (Clark, 1960; Morimoto and Clark, 1961; Barton, 1969; Kretschmar and Scott, 1976; Scott, 1983) and thermal decomposition of FeAsS at 600 to $800^{\circ} \mathrm{C}$ (Strathdee and Pidgeon, 1961; Zviadadze and Rtskhiladze, 1964; Pashinkin et al., 1979). The standard thermodynamic properties of FeAsS derived therefrom, however, exhibit large uncertainties because of the slow equilibration kinetics of arsenopyrite in a dry sulfide system and the inaccuracy of calculated or measured fugacities of sulfur and arsenic gaseous species. Moreover, the extrapolation of these high-temperature properties to $25^{\circ} \mathrm{C}$ is affected by significant uncertainties. As a result, the thermodynamic properties of arsenopyrite reported in the literature are inconsistent and controversial. For example, the widely cited value of the standard molal Gibbs free energy of formation of arsenopyrite at $25^{\circ} \mathrm{C}$ and 1 bar proposed by Barton (1969), $\Delta_{f} G_{1,298}(\mathrm{FeAsS})=-109.6 \mathrm{~kJ} / \mathrm{mol}$, is $\sim 60 \mathrm{~kJ} / \mathrm{mol}$ (!) more negative than the corresponding value given by Wagman et al. (1982): $\Delta_{f} G_{1,298}(\mathrm{FeAsS})=-50.0 \mathrm{~kJ} / \mathrm{mol}$. Such a discrepancy hampers any thermodynamic modeling of water-rock interactions involving FeAsS.

The present study was initiated to better characterize the thermodynamic properties and stability of arsenopyrite at hydrothermal conditions. For this purpose, solubility of arsenopyrite was measured from 300 to $450^{\circ} \mathrm{C}$ in aqueous solution with and without pyrite-pyrrhotite-magnetite assemblage to buffer hydrogen and sulfur fugacities. The results obtained, together with the corresponding data on thermodynamic properties of $\mathrm{As}(\mathrm{OH})_{3}{ }^{\mathrm{O}}(\mathrm{aq})$ and recent heat capacity measurements on arsenopyrite, allow generation of a consistent set of thermody- namic parameters for FeAsS(mon). These new data, combined with available geological information on mineral parageneses of As-rich ore deposits and As contents measured in fluid inclusions and modern hydrothermal sources, are used to predict As-bearing phase equilibria and As transport in geologic fluids.

\section{MATERIALS AND METHODS}

\subsection{Solid Phases}

Dissolution experiments were performed on three natural arsenopyrite samples from the Nikolaevskoe Pb-Zn hydrothermal deposit (Far East, Russia), the Ingichka W skarn-hydrothermal deposit (middle Asia), and the Salsigne Au hydrothermal deposit (France). X-ray diffraction (XRD) and electron microprobe (EMP) analyses showed that all arsenopyrites were highly crystalline, homogeneous, and slightly enriched in sulfur relative to As, with the following average compositions (in atom \%): $\mathrm{Fe}=32.9 \pm 0.3, \mathrm{As}=32.0 \pm 0.5$, and $\mathrm{S}=35.1$ \pm 0.7 , which corresponds to $\mathrm{FeAs}_{0.97} \mathrm{~S}_{1.07}$. No trace elements $(>0.03$ wt.\%), such as $\mathrm{Pb}, \mathrm{Zn}, \mathrm{Co}, \mathrm{Ni}, \mathrm{Mn}, \mathrm{Cu}, \mathrm{Mo}, \mathrm{Sb}$, and $\mathrm{Au}$, were detected. Arsenopyrite crystals were slightly ground, and fine particles were removed by ultrasonic cleaning in acetone.

The pyrite-pyrrhotite-magnetite assemblage (PyPoMt) to buffer $\mathrm{H}_{2}$ and $\mathrm{H}_{2} \mathrm{~S}$ activities in the arsenopyrite dissolution experiments was prepared from Normapur Reagents $\mathrm{FeS}$ and $\mathrm{Fe}_{3} \mathrm{O}_{4}$ and a natural pyrite $\left(\mathrm{FeS}_{2}\right)$ mixed in equal weight proportions (1:1:1). About 20 to $50 \mathrm{~g}$ of this mixture were finely ground and kept in a titanium reactor $(\sim 30$ $\mathrm{cm}^{3}$ ) with an aqueous solution of $0.001-m \mathrm{HCl}$ and $0.01-m \mathrm{H}_{2}$ for 7 to $14 \mathrm{~d}$ at $400^{\circ} \mathrm{C}$ and 500 bar. XRD, scanning electron microscopy (SEM), and EMP analyses of the final product showed the presence of wellcrystalline magnetite, pyrite, and hexagonal pyrrhotite.

\subsection{Analytical Methods}

Aqueous As concentrations were measured using flame atomic absorption spectroscopy (AAS), colorimetry, and titration with iodine, depending on As and sulfur contents in the experiments. Arsenic standard solutions for AAS and colorimetry were prepared by weight dilution of a 1000-ppm As(III) solution obtained by dissolution of a Merck $\mathrm{As}_{2} \mathrm{O}_{3}$ powder in 0.01- $m \mathrm{NaOH}$. Most experimental solutions containing from 5 to $150 \mathrm{ppm}$ of As were analyzed for total As by AAS using acetylene-air flame, an absorption line of $193.7 \mathrm{~nm}$, and a deuterium cathode for background correction. Reproducibility of this method was $\sim 5 \%$, and the detection limit defined at the $2 \sigma$ standard deviation was $1 \mathrm{ppm}$. A few solutions with As concentrations lower than $10 \mathrm{ppm}$ and some selected more concentrated solutions were also analyzed colorimetrically by the molybdate blue method using ascorbic acid as the reducing agent (Pokrovski, 1996). The reproducibility and detection limit were $\pm 2 \%$ and $0.05 \mathrm{ppm}$ As, respectively. Both total As $\left(\mathrm{As}^{(\mathrm{III})}+\mathrm{As}^{(\mathrm{V})}\right)$ and $\mathrm{As} s^{(\mathrm{V})}$ can be analyzed by this method. Arsenicrich $\left(m_{\mathrm{As}}>0.01 \mathrm{~m}\right)$ and sulfur-poor solutions were also analyzed for As(III) by titration with iodine (Charlot, 1966) with a reproducibility of $\pm 1 \%$. Neither colorimetry nor titration detected $\mathrm{As}(\mathrm{V})$ in experimental solutions in the limit of $\pm 2 \%$. Arsenic(III) concentrations of the same experimental solutions analyzed by the three methods were always the same within $\pm 5 \%$.

Aqueous iron concentrations in the range 0.05 to $10 \mathrm{ppm}$ were measured by acetylene-air flame AAS at $248.3 \mathrm{~nm}$ with a reproducibility of $\pm 2 \%$ and a detection limit of $0.03 \mathrm{ppm}$ Fe. Calibration solutions were prepared by dilution of a 1000-ppm Fe Prolabo AAS standard solution using the same reagent concentrations as in the experimental solutions $\left(\mathrm{HCl}, \mathrm{NaOH}, \mathrm{H}_{2} \mathrm{~S}, \mathrm{H}_{3} \mathrm{AsO}_{3}\right.$ ).

Concentrations of aqueous $\mathrm{H}_{2} \mathrm{~S}$, which is the dominant sulfur species at the $T-\mathrm{pH}-f_{\mathrm{O}_{2}}$ conditions of our experiments (Kishima, 1989; Kolonin et al., 1989), were determined (a) by titration with iodine for $\mathrm{H}_{2} \mathrm{~S}$-rich experiments, (b) indirectly from the quantity of precipitated $\mathrm{As}_{2} \mathrm{~S}_{3}$ when quenching or sampling As-rich experimental solutions (see section 2.3), or (c) from the weight loss of arsenopyrite in FeAsS$\mathrm{H}_{2} \mathrm{O}( \pm \mathrm{HCl})$ dissolution experiments (see also section 3.1). The reproducibility of these three methods was about $\pm 20 \%$ of the total $\mathrm{H}_{2} \mathrm{~S}$.

Values of $\mathrm{pH}$ in selected quenched or sampled solutions (see below) 


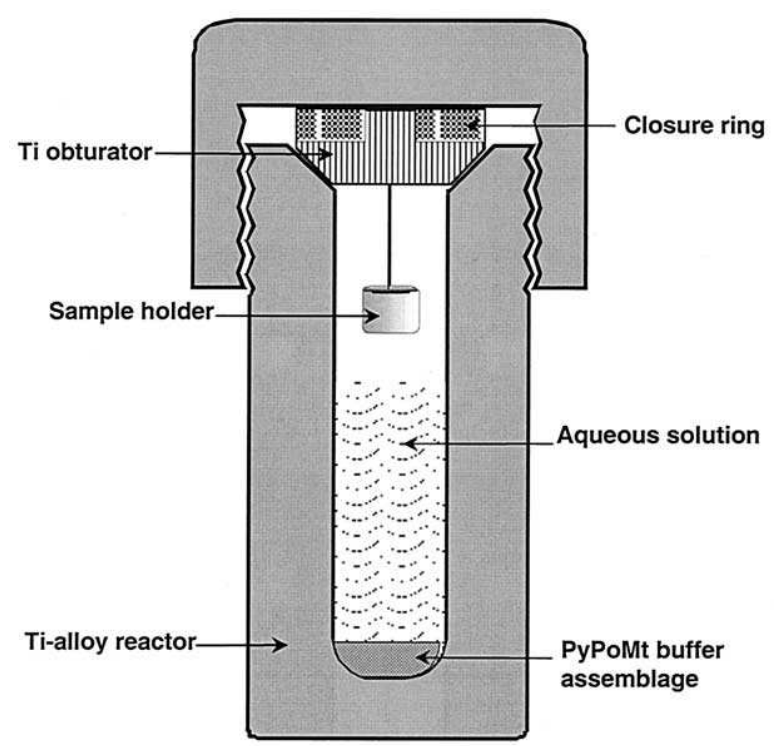

Fig. 1. Schematic drawing of a titanium-alloy autoclave used for arsenopyrite solubility measurements.

were measured at ambient temperature $\left(22 \pm 2^{\circ} \mathrm{C}\right)$ using a Schott 61 combination glass electrode. These values corresponded to those estimated using the initial solution composition and the concentrations of the dissolved components $\left(\mathrm{HCl} / \mathrm{NaOH}+\mathrm{H}_{3} \mathrm{AsO}_{3}+\mathrm{Fe}^{2+}+\mathrm{H}_{2} \mathrm{~S}\right)$.

\subsection{Experimental Procedure}

Arsenopyrite dissolution experiments were performed at temperatures from 300 to $450^{\circ} \mathrm{C}$ and pressures from 100 to 1000 bar in oxygen-free, deionized water or $\mathrm{HCl} / \mathrm{NaOH}$ solutions with or without pyrite-pyrrhotite-magnetite buffering, or in solutions containing excess $\mathrm{H}_{2} \mathrm{~S}$ or $\mathrm{H}_{2}$ (by adding to the reactor the corresponding amount of $\mathrm{Al}_{2} \mathrm{~S}_{3}$ or Al metal, respectively, see Table 1). Precipitation experiments were performed using concentrated solutions of arsenious acid $(0.2-m$ $\mathrm{H}_{3} \mathrm{AsO}_{3}$, see Table 2). Most measurements were carried out using 20to $30-\mathrm{cm}^{3} \mathrm{Ti}$ alloy (Ti, Mo, Al, VT-8) autoclaves quenched at the end of each run (Fig. 1). The reactor volume was measured before the experiment by filling the autoclave with deionized, degassed water at controlled temperature $\left(22 \pm 1{ }^{\circ} \mathrm{C}\right)$. Arsenopyrite crystals were put in a titanium sample holder fixed to the upper part of the reactor so that they did not contact the solution at ambient temperature. Two to four $g$ of pyrite-pyrrhotite-magnetite mixture (if present) were placed at the bottom of the autoclave. Experimental solutions were flushed with $\mathrm{Ar}$ or $\mathrm{H}_{2}$ for $30 \mathrm{~min}$, rapidly weighted, and loaded in the reactor. Arsenopyrite/solution weight ratios ranged from $\sim 1: 400$ to $1: 3$ (see Tables 1 and 2). Pressure was calculated from the degree of filling of the autoclave according to the PVT properties of pure water (Kestin et al., 1984) and assuming that the low concentrations of solutes ( $\mathrm{HCl}$, As, $\mathrm{H}_{2} \mathrm{~S}<\sim 0.1 \mathrm{~mol}$ ) did not significantly modify these properties. The uncertainty of pressure estimation was about \pm 30 bar. The permeability of hydrogen through the autoclave was tested in runs in pure water or $0.01-m \mathrm{HCl}$ by adding metallic aluminum to the reactor. In all tests performed at 350 to $450^{\circ} \mathrm{C}$ and lasting for at least 1 to 2 months, the solutions after experiments demonstrated the presence of important amounts of $\mathrm{H}_{2}$ bubbles rapidly escaping the autoclave after opening. The reactor walls after experiment always presented the characteristic blue-gray color typical of the Ti-oxide protective layer. These tests,

Table 1. Results for FeAsS dissolution experiments in nonbuffered aqueous solutions, and with excess $\mathrm{H}_{2}$ or $\mathrm{H}_{2} \mathrm{~S}$.

\begin{tabular}{|c|c|c|c|c|c|c|c|c|}
\hline $\begin{array}{l}\text { Run } \\
\text { number }\end{array}$ & Initial solution composition & $\begin{array}{l}\text { FeAsS/solution } \\
\text { ratio }(R)\end{array}$ & $\begin{array}{l}\text { Pressure } \\
\text { (bar) }\end{array}$ & $\begin{array}{l}\text { Duration } \\
\text { (d) }\end{array}$ & $\underset{(\mathrm{mol} / \mathrm{kg})}{\mathrm{As}}$ & $\underset{(\mathrm{mol} / \mathrm{kg})}{\mathrm{Fe}}$ & $\begin{array}{c}\mathrm{As} / \mathrm{S} \\
\mathrm{mol} \mathrm{ratio}^{\mathrm{b}}\end{array}$ & $\begin{array}{l}\text { Phases identified } \\
\text { after experiment }\end{array}$ \\
\hline \multicolumn{9}{|l|}{$350^{\circ} \mathrm{C}$} \\
\hline 4 & Pure $\mathrm{H}_{2} \mathrm{O}$ & $1: 280$ & 300 & 7 & 0.0018 & $5.6 \cdot 10^{-6}$ & 0.55 & asp, mt \\
\hline 7 & Pure $\mathrm{H}_{2} \mathrm{O}$ & $1: 150$ & 300 & 12 & 0.0015 & $3.4 \cdot 10^{-6}$ & 0.43 & asp, mt \\
\hline 10 & Pure $\mathrm{H}_{2} \mathrm{O}$ & $1: 140$ & 300 & 37 & 0.0020 & $2.9 \cdot 10^{-6}$ & 0.32 & asp, mt \\
\hline 11 & Pure $\mathrm{H}_{2} \mathrm{O}$ & $1: 140$ & 300 & 37 & 0.0025 & $6.1 \cdot 10^{-6}$ & 0.39 & asp, mt \\
\hline 8 & $0.002 \mathrm{~m} \mathrm{HCl}$ & 1:195 & 300 & 12 & 0.0024 & $7.5 \cdot 10^{-4}$ & 0.35 & asp, mt \\
\hline 5 & $0.01 \mathrm{~m} \mathrm{HCl}$ & $1: 175$ & 300 & 7 & 0.0024 & $2.7 \cdot 10^{-3}$ & 0.53 & asp \\
\hline 12 & $0.01 \mathrm{~m} \mathrm{HCl}$ & $1: 100$ & 320 & 37 & 0.0042 & $4.0 \cdot 10^{-3}$ & 0.20 & asp \\
\hline 6 & $0.05 m \mathrm{HCl}$ & $1: 165$ & 300 & 7 & 0.0047 & $5.6 \cdot 10^{-3}$ & 0.59 & asp, as \\
\hline 9 & $10^{-3} m \mathrm{NaOH}$ & $1: 240$ & 300 & 12 & 0.0012 & $<0.2 \cdot 10^{-6}$ & 0.28 & asp, $\mathrm{mt}$ \\
\hline \multicolumn{9}{|l|}{$400^{\circ} \mathrm{C}$} \\
\hline 421 & $\mathrm{H}_{2} \mathrm{O}$ & $1: 20$ & 100 & 12 & 0.0130 & $<0.2 \cdot 10^{-6}$ & 0.72 & asp, mt \\
\hline 419 & Pure $\mathrm{H}_{2} \mathrm{O}$ & $1: 50$ & 200 & 10 & 0.0120 & $3.4 \cdot 10^{-6}$ & 0.97 & asp, mt \\
\hline 420 & Pure $\mathrm{H}_{2} \mathrm{O}$ & $1: 35$ & 210 & 9 & 0.0180 & $<0.2 \cdot 10^{-6}$ & 1.00 & asp, mt \\
\hline 401 & Pure $\mathrm{H}_{2} \mathrm{O}$ & $1: 95$ & 300 & 7 & 0.0071 & $3.6 \cdot 10^{-6}$ & 0.78 & asp, mt \\
\hline 403 & Pure $\mathrm{H}_{2} \mathrm{O}$ & $1: 100$ & 300 & 7 & 0.0063 & $3.7 \cdot 10^{-6}$ & 0.56 & asp, mt \\
\hline 402 & Pure $\mathrm{H}_{2} \mathrm{O}$ & $1: 150$ & 500 & 7 & 0.0050 & $4.5 \cdot 10^{-6}$ & 0.74 & asp, mt \\
\hline 413 & Pure $\mathrm{H}_{2} \mathrm{O}$ & $1: 280$ & 500 & 3 & 0.0033 & $4.5 \cdot 10^{-6}$ & 0.75 & asp, mt \\
\hline 412 & Pure $\mathrm{H}_{2} \mathrm{O}$ & $1: 195$ & 500 & 12 & 0.0051 & $3.3 \cdot 10^{-6}$ & 0.79 & asp, mt \\
\hline 416 & Pure $\mathrm{H}_{2} \mathrm{O}$ & $1: 75$ & 490 & 7 & 0.0045 & $1.2 \cdot 10^{-6}$ & 0.78 & asp, mt \\
\hline 422 & Pure $\mathrm{H}_{2} \mathrm{O}$ & $1: 120$ & 980 & 10 & 0.0067 & $6.4 \cdot 10^{-6}$ & 0.73 & asp, mt \\
\hline 407 & $0.001 \mathrm{~m} \mathrm{HCl}$ & $1: 190$ & 495 & 7 & 0.0061 & $1.9 \cdot 10^{-4}$ & 0.33 & asp, mt \\
\hline 425 & $0.01 m \mathrm{HCl}$ & $1: 235$ & 500 & 24 & 0.0130 & $4.1 \cdot 10^{-3}$ & 0.40 & asp, mt \\
\hline 405 & $10^{-3} m \mathrm{HCl}+0.1 \mathrm{~m} \mathrm{H}_{2} \mathrm{~S}$ & $1: 340$ & 500 & 7 & 0.0022 & $7.1 \cdot 10^{-5}$ & - & asp, po \\
\hline 406 & $10^{-3} m \mathrm{HCl}+0.22 \mathrm{~m} \mathrm{H}_{2} \mathrm{~S}$ & $1: 260$ & 500 & 7 & 0.0014 & $2.8 \cdot 10^{-5}$ & - & asp, po \\
\hline 426 & $10^{-3} \mathrm{~m} \mathrm{HCl}+0.50 \mathrm{~m} \mathrm{H}_{2} \mathrm{~S}$ & $1: 120$ & 500 & 10 & 0.0009 & $9.8 \cdot 10^{-6}$ & - & asp, po \\
\hline 423 & $0.1 \mathrm{~m} \mathrm{H}_{2}$ & $1: 50$ & 200 & 10 & 0.0008 & $<0.5 \cdot 10^{-6}$ & - & asp, mt (lo?) \\
\hline 404 & $10^{-3} m \mathrm{HCl}+0.1 m \mathrm{H}_{2}$ & $1: 360$ & 490 & 7 & 0.00006 & $2.2 \cdot 10^{-4}$ & - & asp, $\mathrm{mt}$, lo \\
\hline \multicolumn{9}{|c|}{ 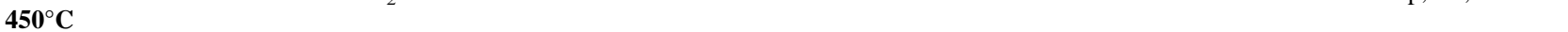 } \\
\hline 3 & Pure $\mathrm{H}_{2} \mathrm{O}$ & $1: 28$ & 500 & 25 & 0.08 & $1.3 \cdot 10^{-5}$ & 0.83 & asp, mt \\
\hline
\end{tabular}

${ }^{\mathrm{a}}$ asp $=$ arsenopyrite; $\mathrm{py}=$ pyrite; $\mathrm{po}=$ pyrrhotite; $\mathrm{mt}=$ magnetite lo $=$ loellingite $\left.(\mathrm{FeAs})_{2}\right)$ as $=$ native arsenic; ? = uncertain .

${ }^{\mathrm{b}} \mathrm{As} / \mathrm{S}$ ratio is determined from FeAsS weight loss after experiment, As and Fe measured concentrations, and the mass balance according to Eqns. 1,2 , or 3 . 
Table 2. Results for FeAsS dissolution/precipitation experiments in aqueous solution in the presence of the pyrite-pyrrhotite-magnetite assemblage.

\begin{tabular}{|c|c|c|c|c|c|c|c|}
\hline Run number & $\begin{array}{l}\text { Initial solution } \\
\text { composition }\end{array}$ & $\begin{array}{c}\mathrm{FeAsS} / \text { solution } \\
\text { ratio }(R)\end{array}$ & $\begin{array}{l}\text { Pressure } \\
\text { (bar) }\end{array}$ & $\begin{array}{l}\text { Duration } \\
\text { (d) }\end{array}$ & As $(\mathrm{mol} / \mathrm{kg})$ & $\mathrm{Fe}(\mathrm{mol} / \mathrm{kg})$ & $\begin{array}{c}\mathrm{H}_{2} \mathrm{~S}^{\mathrm{a}} \\
(\mathrm{mol} / \mathrm{kg})\end{array}$ \\
\hline \multicolumn{8}{|c|}{$\mathbf{3 0 0}^{\circ} \mathbf{C}$ dissolution } \\
\hline 301 & Pure $\mathrm{H}_{2} \mathrm{O}$ & $1: 130$ & 280 & 37 & 0.00026 & $1.3 \cdot 10^{-5}$ & \\
\hline 302 & $0.001 m \mathrm{HCl}$ & $1: 170$ & 430 & 70 & 0.00041 & $9.4 \cdot 10^{-6}$ & \\
\hline 303 & $0.001 \mathrm{~m} \mathrm{HCl}$ & $1: 50$ & 355 & 70 & 0.00040 & $6.9 \cdot 10^{-6}$ & \\
\hline 304 & Pure $\mathrm{H}_{2} \mathrm{O}$ & $1: 55$ & 250 & 70 & 0.00098 & $4.7 \cdot 10^{-6}$ & \\
\hline \multirow[t]{2}{*}{305} & Pure $\mathrm{H}_{2} \mathrm{O}$ & $1: 23$ & 570 & 70 & 0.00075 & $6.2 \cdot 10^{-6}$ & \\
\hline & & & & 3 & 0.00049 & - & \\
\hline \multirow[t]{2}{*}{$\mathrm{COR}-4^{\mathrm{c}}$} & Pure $\mathrm{H}_{2} \mathrm{O}$ & $1: 20$ & 390 & 5 & 0.00056 & - & \\
\hline & & & & 10 & 0.00057 & - & $0.0023^{\mathrm{b}}$ \\
\hline \multicolumn{8}{|c|}{$\mathbf{3 5 0}^{\circ} \mathbf{C}$ dissolution } \\
\hline A & $0.001 \mathrm{~m} \mathrm{HCl}$ & $1: 20$ & 500 & 7 & 0.0048 & $1.2 \cdot 10^{-4}$ & \\
\hline B & $0.001 m \mathrm{HCl}$ & $1: 20$ & 500 & 14 & 0.0070 & $8.0 \cdot 10^{-6}$ & \\
\hline 14 & $0.001 \mathrm{~m} \mathrm{HCl}$ & $1: 18$ & 515 & 125 & 0.0049 & $7.5 \cdot 10^{-6}$ & 0.0063 \\
\hline $\mathrm{C}$ & $0.01 \mathrm{~m} \mathrm{HCl}$ & $1: 20$ & 500 & 7 & 0.0016 & $1.1 \cdot 10^{-3}$ & \\
\hline $\mathrm{D}$ & $0.01 \mathrm{~m} \mathrm{HCl}$ & $1: 20$ & 490 & 14 & 0.0037 & $8.4 \cdot 10^{-5}$ & \\
\hline $\mathrm{E}$ & $0.01 \mathrm{~m} \mathrm{HCl}$ & $1: 20$ & 510 & 21 & 0.0046 & $2.5 \cdot 10^{-5}$ & \\
\hline $\mathrm{F}$ & $0.01 \mathrm{~m} \mathrm{HCl}$ & $1: 20$ & 550 & 30 & 0.0048 & $2.5 \cdot 10^{-5}$ & \\
\hline \multirow[t]{2}{*}{13} & $0.01 \mathrm{~m} \mathrm{HCl}$ & $1: 25$ & 670 & 71 & 0.0067 & $3.4 \cdot 10^{-3}$ & 0.010 \\
\hline & & & & 3 & 0.0030 & $<1 \cdot 10^{-6}$ & \\
\hline \multirow[t]{3}{*}{ COR-4 } & Pure $\mathrm{H}_{2} \mathrm{O}$ & $1: 15$ & 490 & 5 & 0.0037 & $<1 \cdot 10^{-6}$ & \\
\hline & & & & 8 & 0.0059 & $1.7 \cdot 10^{-6}$ & 0.0082 \\
\hline & & & & 12 & 0.0050 & $4.8 \cdot 10^{-6}$ & 0.0060 \\
\hline \multicolumn{8}{|c|}{$350^{\circ} \mathrm{C}$ precipitation } \\
\hline 17 & $0.01 m \mathrm{HCl}, 0.2 \mathrm{~m} \mathrm{H}_{3} \mathrm{AsO}_{3}$ & $1: 62$ & 430 & 43 & 0.14 & $3.2 \cdot 10^{-3}$ & 0.009 \\
\hline 15 & $0.01 m \mathrm{HCl}, 0.2 \mathrm{~m} \mathrm{H}_{3} \mathrm{AsO}_{3}$ & $1: 80$ & 485 & 71 & 0.12 & $1.8 \cdot 10^{-3}$ & 0.012 \\
\hline 16 & $0.01 m \mathrm{HCl}, 0.2 \mathrm{~m} \mathrm{H}_{3} \mathrm{AsO}_{3}$ & $1: 20$ & 580 & 125 & 0.10 & $1.4 \cdot 10^{-3}$ & 0.013 \\
\hline \multicolumn{8}{|c|}{$\mathbf{4 0 0}^{\circ} \mathrm{C}$ dissolution } \\
\hline 427 & Pure $\mathrm{H}_{2} \mathrm{O}$ & $1: 210$ & 485 & 38 & 0.012 & $9.3 \cdot 10^{-5}$ & \\
\hline 414 & $0.001 m \mathrm{HCl}$ & $1: 180$ & 500 & 14 & 0.0049 & $1.5 \cdot 10^{-4}$ & \\
\hline 410 & Pure $\mathrm{H}_{2} \mathrm{O}$ & $1: 175$ & 500 & 7 & 0.0018 & $1.9 \cdot 10^{-5}$ & \\
\hline 417 & Pure $\mathrm{H}_{2} \mathrm{O}$ & $1: 170$ & 490 & 24 & 0.0043 & $1.6 \cdot 10^{-4}$ & \\
\hline 415 & Pure $\mathrm{H}_{2} \mathrm{O}$ & $1: 150$ & 500 & 14 & 0.0050 & $9.0 \cdot 10^{-5}$ & \\
\hline 428 & Pure $\mathrm{H}_{2} \mathrm{O}$ & $1: 150$ & 300 & 37 & 0.0070 & $4.7 \cdot 10^{-5}$ & \\
\hline 411 & $0.001 m \mathrm{HCl}$ & $1: 130$ & 500 & 7 & 0.0062 & $3.4 \cdot 10^{-4}$ & \\
\hline 429 & Pure $\mathrm{H}_{2} \mathrm{O}$ & $1: 95$ & 1050 & 38 & 0.016 & $6.8 \cdot 10^{-5}$ & \\
\hline 430 & $0.001 \mathrm{~m} \mathrm{HCl}, 4.1 \mathrm{~m} \mathrm{NaCl}$ & $1: 17$ & 500 & 65 & 0.057 & $6.4 \cdot 10^{-3}$ & \\
\hline 431 & Pure $\mathrm{H}_{2} \mathrm{O}$ & $1: 12$ & 500 & 34 & 0.032 & $2.7 \cdot 10^{-5}$ & 0.021 \\
\hline 432 & $0.001 m \mathrm{HCl}$ & $1: 14$ & 500 & 57 & 0.038 & $1.5 \cdot 10^{-5}$ & 0.021 \\
\hline \multirow[t]{2}{*}{433} & $0.001 m \mathrm{HCl}$ & $1: 7$ & 500 & 70 & 0.069 & $4.2 \cdot 10^{-5}$ & 0.020 \\
\hline & & & & 1 & 0.059 & $1.4 \cdot 10^{-5}$ & \\
\hline \multirow[t]{3}{*}{ COR-2 } & $0.001 m \mathrm{HCl}$ & $1: 8$ & 450 & 2 & 0.068 & $7.5 \cdot 10^{-6}$ & \\
\hline & & & & 3 & 0.075 & $1.1 \cdot 10^{-5}$ & 0.024 \\
\hline & & & & 6 & 0.073 & $1.1 \cdot 10^{-5}$ & 0.017 \\
\hline \multicolumn{8}{|c|}{$\mathbf{4 5 0}^{\circ} \mathbf{C}$ dissolution } \\
\hline 6 & Pure $\mathrm{H}_{2} \mathrm{O}$ & $1: 39$ & 510 & 8 & 0.055 & $1.3 \cdot 10^{-5}$ & \\
\hline 7 & Pure $\mathrm{H}_{2} \mathrm{O}$ & $1: 32$ & 520 & 15 & 0.093 & $1.4 \cdot 10^{-5}$ & \\
\hline 1 & Pure $\mathrm{H}_{2} \mathrm{O}$ & $1: 24$ & 520 & 25 & 0.125 & $2.0 \cdot 10^{-5}$ & \\
\hline 11 & $0.0001 \mathrm{~m} \mathrm{HCl}$ & $1: 13$ & 525 & 46 & 0.180 & $4.1 \cdot 10^{-5}$ & \\
\hline 9 & $0.001 \mathrm{~m} \mathrm{HCl}$ & $1: 40$ & 530 & 46 & 0.096 & $8.9 \cdot 10^{-5}$ & \\
\hline 13 & $0.001 \mathrm{~m} \mathrm{HCl}$ & $1: 11$ & 540 & 48 & 0.330 & $1.5 \cdot 10^{-4}$ & 0.120 \\
\hline 14 & $0.001 m \mathrm{HCl}$ & $1: 6$ & 540 & 63 & 0.320 & $4.5 \cdot 10^{-5}$ & 0.135 \\
\hline 12 & $0.001 m \mathrm{HCl}$ & $1: 3$ & 530 & 63 & 0.320 & $5.9 \cdot 10^{-5}$ & 0.105 \\
\hline
\end{tabular}

${ }^{a}$ Calculated from the difference between As concentrations in acid and alkaline filtrates and assuming that all sulfide was trapped by As $\mathrm{S}_{3}$ formed during solution cooling (see text for details).

betermined by titration with iodine.

Uncertainties for the $\mathrm{H}_{2} \mathrm{~S}$ concentrations reported in the table are about 20 to $30 \%$ of the value.

${ }^{\mathrm{c}} \mathrm{COR}=$ runs were conducted using a flexible-cell autoclave (Coretest; see text).

Arsenic concentrations in bold, italic type were assumed to be at equilibrium and were used in the calculation of the Gibbs free energy of arsenopyrite (see text and Table 3).

although qualitative, showed that both hydrogen diffusion through the reactor's walls and Ti-hydride formation were negligible in our experiments. The impermeability of our autoclaves to hydrogen is also in agreement with experiments (by measuring $\mathrm{H}_{2}$ pressure) performed by Gibert et al. (1998) on much thinner Ti cells in a Coretest apparatus (see below). 
The autoclaves were placed in temperature-controlled $\left( \pm 2^{\circ} \mathrm{C}\right)$, preheated ovens. At the end of the run, the reactor was quenched in cold water, separating the FeAsS crystals from the solution. The quenched solutions always contained yellow colloidal $\mathrm{As}_{2} \mathrm{~S}_{3}$, which formed on cooling. The solutions remained homogeneous, however, and no significant accumulation of the arsenic sulfide colloids at the bottom of the reactor was observed within at least an hour after quenching. The solution was rapidly extracted from the reactor and divided into three parts. One part $(\sim 3 \mathrm{~mL})$ of the quenched solution was used to measure $\mathrm{pH}$. The second part was acidified with $1 \mathrm{~mol} / \mathrm{L} \mathrm{HCl}$ to a $\mathrm{pH} \sim 2$ and filtered through a $0.1-\mu \mathrm{m}$ cellulose filter to remove the arsenic sulfide (solution A). The third part was basified with $1 \mathrm{~mol} / \mathrm{L} \mathrm{NaOH}$ to a $\mathrm{pH}$ $\sim 11$ to 12 to completely dissolve the $\mathrm{As}_{2} \mathrm{~S}_{3}$ precipitate and filtered through a $0.45-\mu m$ filter (solution B). The PyPoMt mixture (if present) and reactor's walls were then washed with a weighed amount of 0.01 $\mathrm{mol} / \mathrm{L} \mathrm{NaOH}$ to remove the residue of precipitated $\mathrm{As}_{2} \mathrm{~S}_{3}$ (solution C). All three solutions were weighed, diluted, and analyzed for As and Fe. Total As concentration in the experiment was calculated from those determined in solutions $\mathrm{B}$ and $\mathrm{C}$ and using the corresponding dilution factors, solution weights, and the mass of fluid loaded in the reactor. For most experiments, the quantity of As derived from the analysis of the washing solution (C) did not exceed $20 \%$ of the total value. In As-rich experiments $\left(\mathrm{As} / \mathrm{S}_{\mathrm{mol}}>\sim 1\right)$, all sulfur is likely to precipitate in the form of $\mathrm{As}_{2} \mathrm{~S}_{3}$ when cooling to room temperature. This is in agreement with the rapid formation and low solubility of amorphous $\mathrm{As}_{2} \mathrm{~S}_{3}$ in acid to neutral solutions at ambient temperature (e.g., $m_{\mathrm{H}_{2} \mathrm{~S}}$ in solution in equilibrium with $\mathrm{As}_{2} \mathrm{~S}_{3}(\mathrm{am})$ at $25^{\circ} \mathrm{C}<3 \times 10^{-4} \mathrm{~mol}$; Eary, 1992). Therefore, the difference in the As quantity between solutions $B$ $+\mathrm{C}$ and $\mathrm{A}$, which corresponds to $\mathrm{As}_{2} \mathrm{~S}_{3}$, was used to estimate the $\mathrm{H}_{2} \mathrm{~S}$ concentration in some of As-rich experiments (see Table 2). In several sulfur-rich experiments, $\mathrm{H}_{2} \mathrm{~S}$ concentrations were also determined by titration with iodine (see section 2.2) and were found to be close to the initial $\mathrm{H}_{2} \mathrm{~S}$ loaded in the reactor (see Table 1). Iron concentrations analyzed in solutions A and B were always the same, demonstrating the absence of Fe adsorption on or coprecipitation with colloidal $\mathrm{As}_{2} \mathrm{~S}_{3}$. The presence of iron(II)-hydroxide colloids in the quenched solutions can be also excluded for the same reason. Because the formation of colloids of metallic hydroxides is generally very sensitive to $\mathrm{pH}$, the similar Fe concentrations obtained from acid (A) and basic (B) solutions demonstrate that such colloids are likely to be negligible in the quenched experimental solutions. Iron concentrations, measured in solution (C) from experiments without PyPoMt buffering, were in most cases negligible, demonstrating the absence of iron phases precipitation on the reactor walls during quenching.

A few experiments were also performed using a rocking flexible-cell hydrothermal apparatus (Coretest). Details on the vessel design and experimental procedure are given elsewhere (Gibert et al., 1998). Solids and solution were loaded in a $\sim 100-\mathrm{cm}^{3}$ titanium reaction cell, inserted into a $316 \mathrm{SS}$ autoclave filled with water (used as the pressure medium), and placed in a rocking, temperature-controlled $\left( \pm 2^{\circ} \mathrm{C}\right)$ furnace. Pressure was imposed in the external vessel using a water pump and maintained within \pm 10 bar. Samples $(\sim 5 \mathrm{~mL})$ were periodically taken through an external Ti sampling tube and valve. Because in all experiments, $\mathrm{As}_{2} \mathrm{~S}_{3}$ precipitated during sampling, the extracted solutions were treated similarly to solutions A and B from the experiments in closed reactors (see above).

After each experiment, the FeAsS crystals and PyPoMt mixture were carefully examined using optical microscopy, EPM, SEM, XRD, and Raman spectroscopy to check for newly formed phases and determine their composition.

\section{EXPERIMENTAL RESULTS}

\subsection{Arsenopyrite Solubility in $\mathrm{H}_{2} \mathrm{O}-\mathrm{HCl} / \mathrm{NaOH}-$ and $\mathrm{H}_{2}$ / $\mathrm{H}_{2}$ S-Bearing Solutions Without PyPoMt}

The results of FeAsS dissolution experiments at 350, 400, and $450^{\circ} \mathrm{C}$ in the absence of PyPoMt are summarized in Table 1. Arsenic concentrations, determined in FeAsS dissolution experiments in pure water at 350 and $400^{\circ} \mathrm{C}$, are plotted as a function of dissolution time in Fig. 2a. The examination of this figure and Table 1 shows that As and Fe concentrations attain a steady state within a week. Although no rigorous kinetic tests were performed for other solution compositions $(\mathrm{HCl}, \mathrm{NaOH}$, $\mathrm{H}_{2}, \mathrm{H}_{2} \mathrm{~S}$ ), following the results obtained in pure water, it was assumed that 7 to $10 \mathrm{~d}$ were sufficient to attain a steady state at temperatures 350 to $450^{\circ} \mathrm{C}$. This is also in agreement with a previous study of $\mathrm{FeAsS}$ dissolution in pure water at $350^{\circ} \mathrm{C}$ and 500 bar (Pal'yanova and Kolonin, 1992) in which a steady state was attained within $10 \mathrm{~d}$ with similar solid/solution ratios $(R$ $\sim 1: 50$ to 200 ).

It was found that in pure water and 0.001-m $\mathrm{HCl}$ or $\mathrm{NaOH}$ solutions at $350^{\circ} \mathrm{C}, 400$, and $450^{\circ} \mathrm{C}$ and in $0.01-\mathrm{m} \mathrm{HCl}$ at $400^{\circ} \mathrm{C}$ and all pressures investigated (100 to 1000 bar), arsenopyrite dissolves with formation of magnetite (Fig. 3a), according to the reaction

$$
\begin{aligned}
\mathrm{FeAs}_{0.97} \mathrm{~S}_{1.07}+4.242 \mathrm{H}_{2} \mathrm{O} & =0.333 \mathrm{Fe}_{3} \mathrm{O}_{4}+0.97 \mathrm{As}(\mathrm{OH})_{3}^{0}(\mathrm{aq}) \\
& +1.07 \mathrm{H}_{2} \mathrm{~S}^{0}(\mathrm{aq})+1.717 \mathrm{H}_{2}^{0}(\mathrm{aq})
\end{aligned}
$$

This reaction is consistent with the predominance of $\mathrm{As}(\mathrm{OH})_{3}{ }^{\mathrm{O}}(\mathrm{aq})$ and $\mathrm{H}_{2} \mathrm{~S}^{\mathrm{O}}$ (aq) species for arsenic (Pokrovski et al., 1996) and sulfur (Kishima, 1989; Kolonin et al., 1989; Gibert et al., 1998), respectively, at the experimental conditions of the present study. In some experiments, however, $\mathrm{H}_{2} \mathrm{~S}$ concentrations calculated according to Eqn. 1 using the measured As concentrations and weight loss of arsenopyrite crystals were found to be slightly higher $\left(\mathrm{As} / \mathrm{S}_{\mathrm{mol}} \sim 0.4\right.$ to 0.9 ; Table 1$)$ than those that should stem from the nonstoichiometry of our arsenopyrite $\left(\mathrm{FeAs}_{0.97} \mathrm{~S}_{1.07}, \mathrm{As} / \mathrm{S}=0.90\right)$. Similar solution enrichments by $\mathrm{S}$ vs. As (As/S $\sim 0.3$ to 0.8 ) were reported by Kolonin et al. (1989) and Pal'yanova and Kolonin (1992) in their studies of $\mathrm{FeAsS}\left( \pm \mathrm{Fe}_{3} \mathrm{O}_{4}\right)$ dissolution in $\mathrm{H}_{2} \mathrm{O} \pm \mathrm{HCl} /$ $\mathrm{NaOH}$ from 200 to $350^{\circ} \mathrm{C}$, on the basis of analyses of $\mathrm{H}_{2} \mathrm{~S}$ by titration with iodine in solutions quenched after experiments. The As/S ratios derived in their work and the present study are likely to be explained by the formation of an FeAs-like solid phase or As-enriched zones on FeAsS. Indeed, EMP analyses of arsenopyrite crystals from several $\mathrm{H}_{2} \mathrm{O}-\mathrm{HCl}$ dissolution runs carried out on zones near crystals' surfaces $(\sim 3$ to $10 \mu \mathrm{m}$ from the crystal edge) demonstrated in some cases strong variations in arsenopyrite compositions with an enrichment by arsenic: $\mathrm{Fe}_{1} \mathrm{As}_{1.2 \pm 0.1} \mathrm{~S}_{0.9 \pm 0.2}$. These As-rich zones, however, were erratically distributed, and other near-surface zones demonstrated compositions identical to those of the pristine arsenopyrite. The erratic As enrichment of the FeAsS surface is also confirmed by the strong variations of the As/S solution ratios reported in Table 1. Such variations indicate that the observed As-rich compositions are metastable, and their formation is likely to be caused by different As and $\mathrm{S}$ dissolution rates, with a more rapid departure of sulfur into the solution, which can occur during the initial stages of the dissolution process. At final stages of dissolution, when solution concentrations approach equilibrium, As and $\mathrm{H}_{2} \mathrm{~S}$ dissolution rates should become similar, and the formation of such As-rich zones ceases. However, because of the "refractory nature" of Fe-As phases and the slow kinetics of solid-phase transformations (see below), this newly formed As-rich arsenopyrite does not disappear completely but is no longer involved in the arsenopyrite-solution equilibrium. This hypothesis is also in agreement with thermodynamic calculations (see below) that demonstrate that FeAs-like phases 
(A)

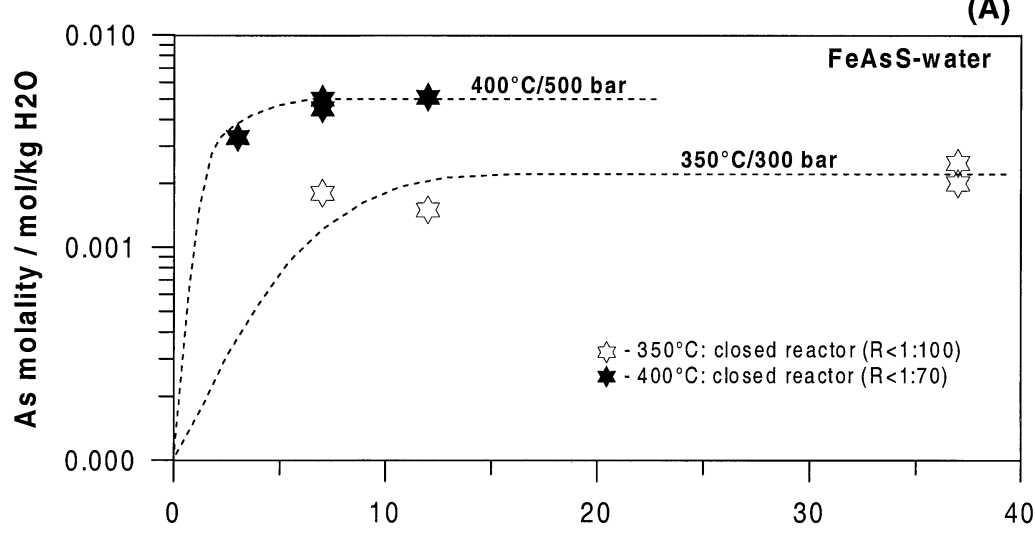

(B)
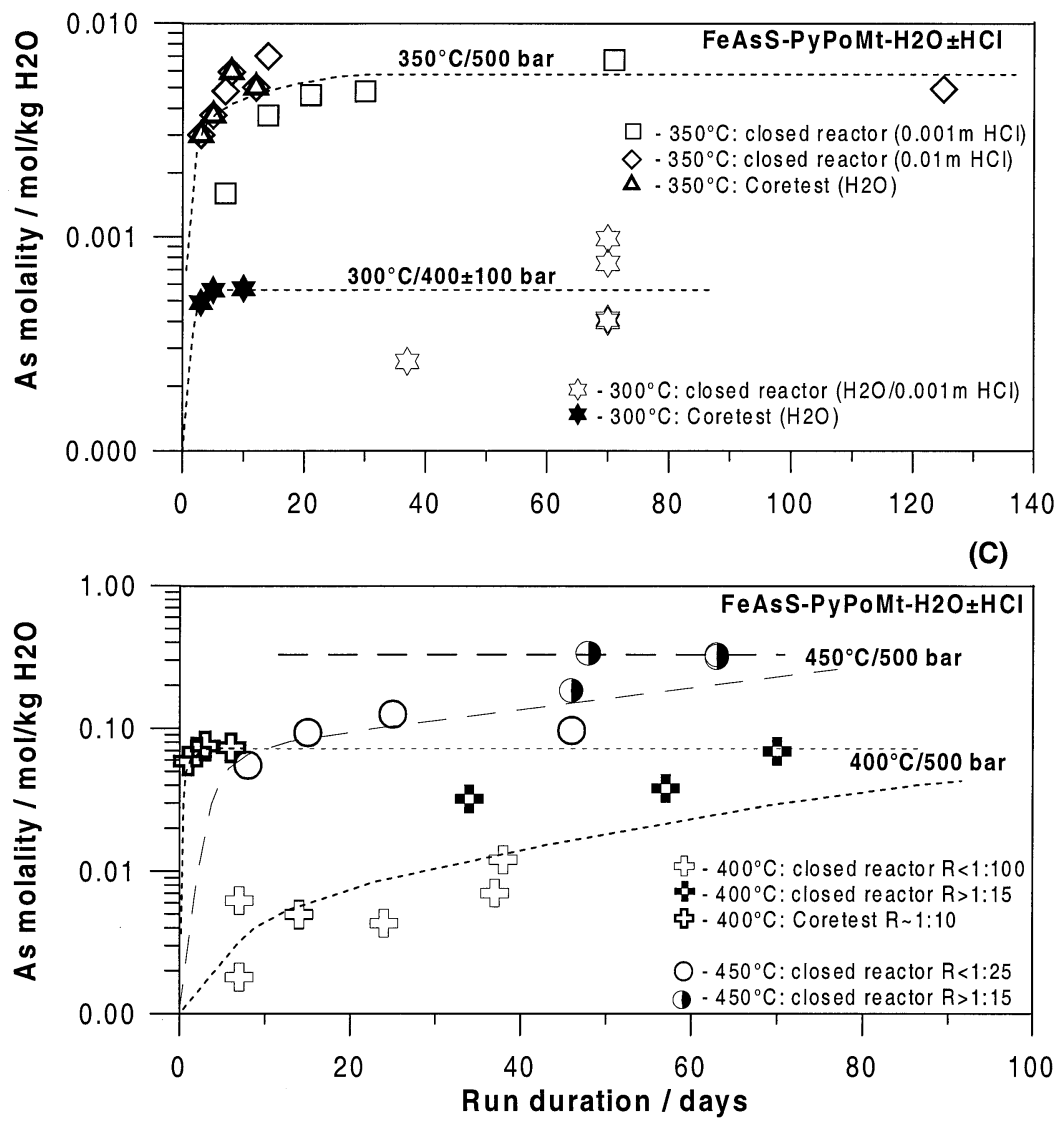

Fig. 2. Arsenic concentrations measured as a function of time in arsenopyrite dissolution runs conducted in pure water without buffer (A), in $\mathrm{H}_{2} \mathrm{O}-\mathrm{HCl}$ solutions in the presence of PyPoMt assemblage at 300 and $350^{\circ} \mathrm{C}(\mathrm{B})$, and at 400 and $450^{\circ} \mathrm{C}(\mathrm{C})$. The symbols denote different runs at indicated conditions (see text and Tables 1 and 2 for details). The dashed lines are drawn to aid the eye. It can be seen that similar steady states for As concentration are attained at the same $T-P$ conditions for experiments carried out either by quenching (closed reactor) or sampling (Coretest) and with different solid/solution ratios and acidities ( $\sim \mathrm{HCl}$ concentration).

are not stable in equilibrium with $\mathrm{FeAsS}$ and $\mathrm{H}_{2} \mathrm{O} / \mathrm{HCl}(\mathrm{NaOH})$ solutions. Following these considerations and the small and irreproducible quantities of these As-enriched zones detected in our $\mathrm{FeAsS}$ dissolution experiments in pure water and $\mathrm{HCl} /$ $\mathrm{NaOH}$ solutions, we decided to not consider their formation in the equilibrium calculations (see below). Therefore, further analysis of these experiments in nonbuffered solutions is based on major phase compositions and measured As and Fe concentrations.
In 0.01- $\mathrm{m} \mathrm{HCl}$ solutions at $350^{\circ} \mathrm{C}$ (runs $350 / 5$ and $350 / 12$ ), As and $\mathrm{Fe}$ total concentrations were found to be similar, and no new phases were observed after experiments (Table 1). This is consistent with a stoichiometric dissolution of arsenopyrite:

$$
\begin{aligned}
\mathrm{FeAs}_{0.97} \mathrm{~S}_{1.07}+3 \mathrm{H}_{2} \mathrm{O}+2 \mathrm{H}^{+}+2 \mathrm{Cl}^{-}=\mathrm{FeCl}_{2}^{0}(\mathrm{aq}) \\
\quad+0.97 \mathrm{As}(\mathrm{OH})_{3}^{0}(\mathrm{aq})+1.07 \mathrm{H}_{2} \mathrm{~S}^{0}(\mathrm{aq})+1.48 \mathrm{H}_{2}^{0}(\mathrm{aq})
\end{aligned}
$$



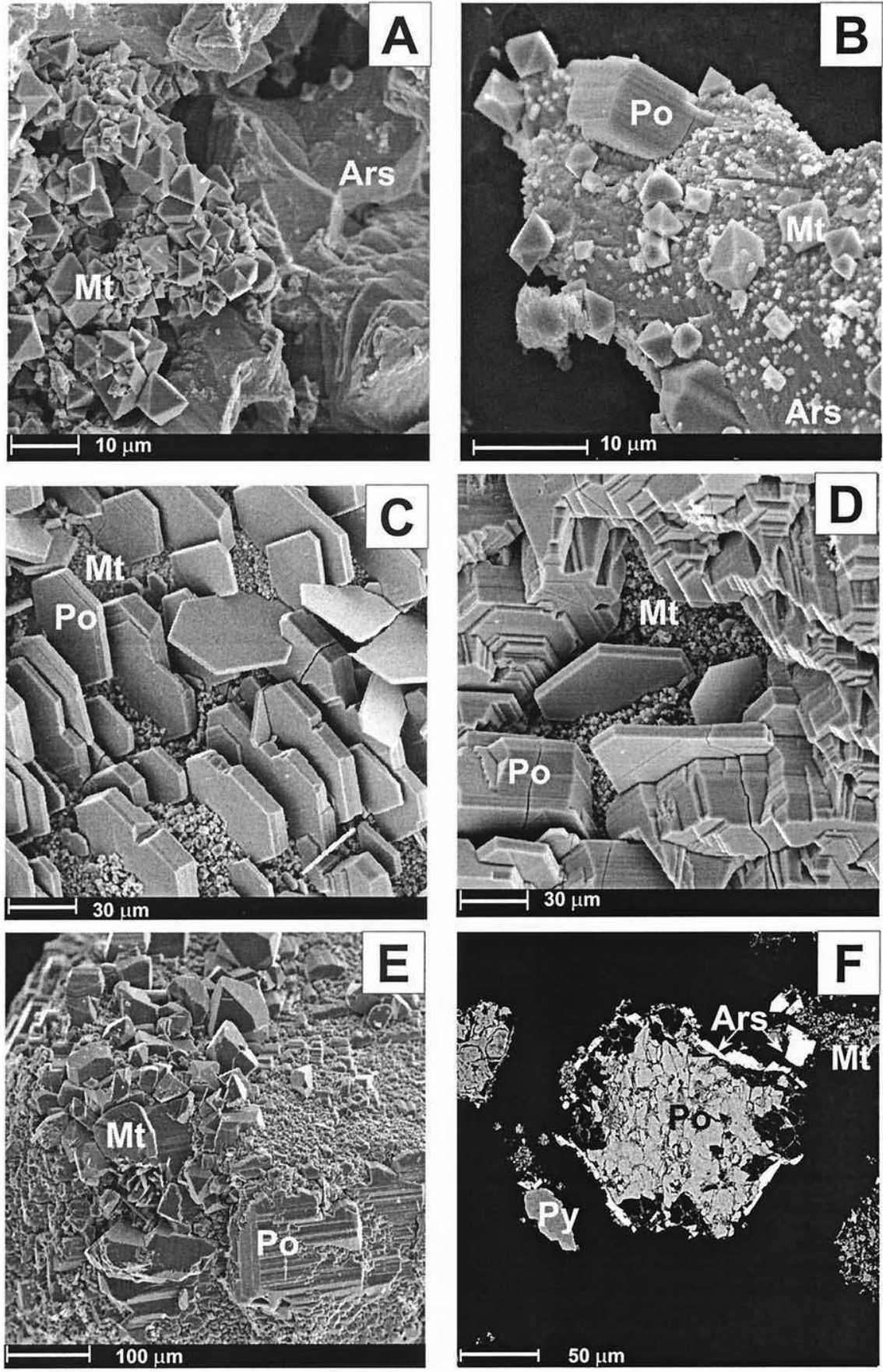

Fig. 3. Scanning electron microscope photomicrographs of the surfaces of arsenopyrite crystals (A to E) and arsenopyritepyrite-pyrrhotite-magnetite assemblage (F) after typical dissolution/precipitation experiments (see Tables 1 and 2). (A) Magnetite (octahedrons) growing on the surface of arsenopyrite at $400^{\circ} \mathrm{C}$ and 500 bar in a $0.01-m \mathrm{HCl}$ solution (run 425). (B) Magnetite (octahedrons) and pyrrhotite growing on the surface of arsenopyrite at $350^{\circ} \mathrm{C}$ and 500 bar in a $0.001-m \mathrm{HCl}$ solution in the presence of PyPoMt buffer (run 350/14). (C) Pyrrhotite (hexagonal plates) and magnetite (small grains in between) formed on the surface of arsenopyrite after $24 \mathrm{~d}$ of experiment at $400^{\circ} \mathrm{C}$ and $500 \mathrm{bar}$ in water in the presence of PyPoMt (run 417). (D) Growth and thickening of pyrrhotite crystals on the surface of arsenopyrite after $37 \mathrm{~d}$ of experiment at $400^{\circ} \mathrm{C}$ and $500 \mathrm{bar}$ in water in the presence of PyPoMt (run 427). (E) Pyrrhotite and magnetite coating the surface of arsenopyrite in a $0.001-m \mathrm{HCl}$ solution at $450^{\circ} \mathrm{C}$ and 500 bar in the presence of PyPoMt (run 450/14). (F) Back-scattered electron image of a polished section of PyPoMt assemblage and newly formed arsenopyrite (white) after a precipitation experiment at $350^{\circ} \mathrm{C}$ and $500 \mathrm{bar}$ (run 350/16). Ars = arsenopyrite; Py = pyrite; Po = pyrrhotite; Mt $=$ magnetite 
At higher $\mathrm{HCl}$ content $(0.05 \mathrm{~m})$, small amounts of native As were detected together with the dominant arsenopyrite in the solid phase after experiment:

$$
\begin{aligned}
\mathrm{FeAs}_{0.97} \mathrm{~S}_{1.07}+2 \mathrm{Cl}^{-}=\mathrm{FeCl}_{2}^{0}(\mathrm{aq}) & +0.97 \mathrm{As}(\mathrm{cr}) \\
& +1.07 \mathrm{H}_{2} \mathrm{~S}^{0}(\mathrm{aq})
\end{aligned}
$$

The formation of native As is consistent with the measured As concentrations lower than those of iron (run 350/6). Stoichiometric FeAsS dissolution in slightly acid solutions $\left(m_{\mathrm{HCl}}=\right.$ $0.001 \mathrm{~m}$ ) and native As formation at lower $\mathrm{pH}$ were also observed in the experiments of Kolonin et al. (1989) at $200^{\circ} \mathrm{C}$. The stability fields of $\mathrm{FeAsS}$ alone and $\mathrm{FeAsS}-\mathrm{As}$ at $400^{\circ} \mathrm{C}$ are likely to occur at much higher $\mathrm{HCl}$ content, not covered by our experiments, because even at $0.01-m \mathrm{HCl}$, the $\mathrm{FeAsS}-\mathrm{Fe}_{3} \mathrm{O}_{4}$ assemblage was still observed (run 425).

In $\mathrm{H}_{2} \mathrm{~S}$-rich aqueous solutions $\left(\geq 0.1-\mathrm{m} \mathrm{H}_{2} \mathrm{~S}\right.$; runs 405,406 , and 426 ), the arsenopyrite-pyrrhotite assemblage forms. Although the small quantities of pyrrhotite formed did not allow us to determine with precision its composition, hexagonal prisms and plates observed by SEM (see below) are consistent with the hexagonal pyrrhotite $\mathrm{Fe}_{0.86-0.90} \mathrm{~S}$, which is stable between 300 and $500^{\circ} \mathrm{C}$ (Toulmin and Barton, 1964). In the presence of $0.1-\mathrm{m} \mathrm{H}_{2}$ (runs 423 and 404), SEM and EPM analyses of the reaction products indicated the formation of loellingite $\left(\mathrm{FeAs}_{2}\right)$ and magnetite. Because the attainment of a steady state for As and Fe concentrations in these $\mathrm{H}_{2} \mathrm{~S}$ and $\mathrm{H}_{2}$-rich solutions was not clearly established, these data were used only for qualitative comparisons with chemical equilibrium calculations (see below).

\subsection{Arsenopyrite Solubility in Aqueous Solution in the Presence of the PyPoMt Buffer}

The results of FeAsS dissolution experiments in pure water and $0.001-$ to $0.01-m \mathrm{HCl}$ solutions in the presence of the PyPoMt buffer are reported in Table 2. The four solid phases (arsenopyrite, pyrite, pyrrhotite, and magnetite) were present after all runs, and no other phases were detected. Arsenopyrite bulk composition remained unchanged in comparison to the initial product $\left(\mathrm{FeAs}_{0.97 \pm 0.02} \mathrm{~S}_{1.07 \pm 0.02}\right)$, and no As enrichment was observed in near-surface zones of arsenopyrite. However, the arsenopyrite surface was found to be highly altered, presenting traces of dissolution, and newly formed pyrrhotite and sometimes magnetite and pyrite. The degree of arsenopyrite surface alteration and the quantity of neoformed minerals increased with temperature (Figs. 3b, 3c, and 3e), which is consistent with the solubility increase (Table 2). In runs with low arsenopyrite/solution ratios at $400^{\circ} \mathrm{C}$, the surface alteration also increased with time (Figs. $3 \mathrm{c}$ and $3 \mathrm{~d}$ ), suggesting a continuing reaction progress, which is also confirmed by an increase of As concentration with time in these experiments (Table 2; runs 410, 417, and 427). In all experiments, the pyrrhotite formed on the arsenopyrite surface or originally present in the PyPoMt mixture was found to correspond to hexagonal pyrrhotite having the same chemical formulae $\mathrm{Fe}_{0.90-0.85} \mathrm{~S}$. This is in good agreement with the composition of hexagonal pyrrhotite $\mathrm{Fe}_{0.88 \pm 0.02} \mathrm{~S}$ existing in the temperature range 300 to $500^{\circ} \mathrm{C}$ in equilibrium with pyrite in a dry system (Toulmin and Barton, 1964; Yund and Hall, 1969) and with pyrite + magnetite in aqueous solution (Kishima, 1989). Microscopic observations and SEM and EPM analyses of both pyrite and magnetite showed a good crystallinity and compositions close to stoichiometric: $\mathrm{FeS}_{2.05} \pm 0.05$ and $\mathrm{Fe}_{3} \mathrm{O}_{4}$, respectively. No As was detected $(<0.2$ wt. $\%)$ in the iron sulfides after the experiments, indicating that As is not incorporated in these minerals at the conditions of this study.

Hydrogen sulfide aqueous concentrations determined in selected runs from the quantity of precipitated $\mathrm{As}_{2} \mathrm{~S}_{3}$ during quenching or sampling (see section 2.3) are also reported in Table 2. These concentrations are constant at each temperature and pressure for both dissolution and precipitation experiments and independent of the run duration in the limit of their uncertainties $( \pm 30 \%)$. The $\mathrm{H}_{2} \mathrm{~S}$ contents determined in this study are in reasonable agreement with those measured by Kishima (1989) and Plyasunova and Ivanov (1991) in aqueous solution in equilibrium with the PyPoMt assemblage. For example, $\mathrm{H}_{2} \mathrm{~S}$ aqueous concentrations reported by Kishima (1989) at 300, 350,400 , and $450^{\circ} \mathrm{C}$ and 500 bar are, respectively, 0.0023 , $0.0075,0.023$, and $0.08 \mathrm{~mol} / \mathrm{kg}$, whereas the corresponding values obtained in the present study are $0.0023 \pm 0.0009,0.008$ $\pm 0.002,0.022 \pm 0.002$, and $0.12 \pm 0.02 \mathrm{~mol} / \mathrm{kg}$, respectively (Table 2). It follows that analyses of both solid phases and $\mathrm{H}_{2} \mathrm{~S}$ concentrations in our experiments demonstrate a rapid attainment of equilibrium between aqueous solution and the PyPoMt assemblage at all temperatures studied, in agreement with previous investigations.

It can be seen in Table 2 and Fig. $2 b$ that As aqueous concentrations measured in the dissolution experiments carried out with low to moderate FeAsS/solution ratios $(1: 170 \leq R \leq$ $1: 20)$ at 300 and $350^{\circ} \mathrm{C}$ attain a steady state value after a month and 1 to 2 weeks, respectively. By contrast, at 400 and $450^{\circ} \mathrm{C}$ and similar $R$, the attainment of a steady state is significantly slower (Fig. 2c). In a preliminary study (Pokrovski et al., 2000), the apparent constancy of As concentrations in a few experiments with low $R$ at $400^{\circ} \mathrm{C}$ and 500 bar lasting between 7 and $24 \mathrm{~d}$ (runs 411, 414, 415, and 417) was attributed to a steady state. Later experiments demonstrated, however, a continuing increase of As concentrations with time at low $R$ (e.g., runs 427 and 429). Only at higher $R(\geq 1: 10)$ is a steady state unambiguously attained at 400 (runs 433 and COR-2) and $450^{\circ} \mathrm{C}$ (runs 12, 13, and 14) (Fig. 2c). The apparent slow dissolution rate of FeAsS observed at high temperatures can be explained by the formation of pyrrhotite and/or magnetite layers and crystals on the FeAsS surface. Because FeAsS dissolution is likely to be surface controlled, and the degree of FeAsS surface coating by the newly formed phases rapidly increases with temperature (see Fig. 3), at similar initial FeAsS/solution ratios, less surface is available at high than at low temperature for As departure into the solution. This also explains the relatively rapid attainment of a steady state in the FeAsS dissolution experiments with PyPoMt buffer at 300 and $350^{\circ} \mathrm{C}$ (Fig. 2b) and in the nonbuffered runs at 350 and $400^{\circ} \mathrm{C}$ (section 3.1, Table 1, Fig. 2a), in which FeAsS surface coating with the neoformed magnetite was weak (Fig. 3a). It was thus assumed that true equilibrium with $\mathrm{FeAsS}$ in the presence of the PyPoMt buffer was achieved in the runs at 300 and $350^{\circ} \mathrm{C}$ with low to moderate $R$ and at 400 and $450^{\circ} \mathrm{C}$ with $R$ higher than 1:20. These experiments are shown in bold, italic type in Table 2. It can be seen in this table and Figs. $2 b$ and $2 c$ that at all 
temperatures investigated, equilibrium As concentrations are independent of solution composition, ranging from pure water to $0.01-m \mathrm{HCl}$. This confirms again that the neutral $\mathrm{As}(\mathrm{OH})_{3}{ }^{\circ}(\mathrm{aq})$ species is the dominant As complex in our experiments.

Several experiments were also performed at $350^{\circ} \mathrm{C}$ starting from solutions supersaturated with respect to FeAsS to demonstrate equilibrium reversibility. Supersaturation was achieved using a concentrated $\mathrm{H}_{3} \mathrm{AsO}_{3}$ solution (0.2- $m$ As) loaded in the reactor at the beginning (Table 2; runs 350/15, 16, and 17). A very slow but constant FeAsS precipitation without attainment of a steady state even after 4 months of reaction was detected. SEM and XRD analyses unambiguously confirmed FeAsS formation in these runs (Fig. 3f). This reluctant FeAsS precipitation can be explained by both the rapid surface coating with newly formed Fe-oxide and -sulfide phases and the refractory nature of arsenopyrite, which is difficult to equilibrate. Note that extremely slow reaction rates were observed in the $\mathrm{Fe}$-As-S dry system at temperatures below $600^{\circ} \mathrm{C}$ (Barton, 1970; Kretschmar and Scott, 1976). Arsenopyrite was also shown to not readily equilibrate on cooling or changing sulfur fugacity (Kretschmar and Scott, 1976; Scott, 1983) and was also difficult to synthesize hydrothermally (Scott, 1975). Consequently, only FeAsS solubilities measured from undersaturation were considered in this study.

\section{DISCUSSION}

\subsection{Conventions, units, and standard states}

The Gibbs free energies (and enthalpies) of minerals, gases, and aqueous species are represented in this study as apparent standard molal Gibbs free energies $\left(\Delta G_{P, T}^{0}\right)$ and enthalpies $\left(\Delta H_{P, T}^{0}\right)$ of formation from the elements at the subscripted pressure $(P)$ and temperature $(T)$ (Tanger and Helgeson, 1988):

$$
\Delta G_{P, T}^{0}=\Delta_{f} G^{0}+\left(G_{P, T}^{0}-G_{P_{r}, T_{r}}^{0}\right),
$$

where $\Delta_{f} G^{0}$ is the standard molal Gibbs free energy of formation of the species from its elements in their stable state at the reference pressure $\left(P_{r}=1 \mathrm{bar}\right)$ and temperature $\left(T_{r}=298.15\right.$ $\mathrm{K})$, and $\left(G_{P, T}^{0}-G_{P_{r}, T_{r}}^{0}\right)$ refers to differences in the standard molal Gibbs free energy of the species that arise from changes in pressure $\left(P-P_{r}\right)$ and temperature $\left(T-T_{r}\right)$. The reference states for the elements (for which $\Delta G_{1,298}^{0}\left(\Delta H_{1,298}^{0}\right)=0$ ) in the system Fe-As-S-O-H are metallic iron ( $\alpha$-Fe, cubic); native arsenic (As, rhombohedrol); solid/liquid sulfur; $\mathrm{O}_{2}$, ideal gas; and $\mathrm{H}_{2}$, ideal gas. The standard states for the solid phases and $\mathrm{H}_{2} \mathrm{O}$ are unit activity for the pure phase at all temperatures and pressures. For aqueous species, the reference state convention corresponds to unit activity coefficient for a hypothetical 1-m solution whose behavior is ideal. Aqueous species concentrations are expressed in molal units $\left(\mathrm{mol} / \mathrm{kg} \mathrm{H}_{2} \mathrm{O}\right.$ ). Activity coefficients $\left(\gamma_{i}\right)$ of neutral aqueous species were assumed to be unity, but those of charged species were calculated using the extended Debye-Hückel equation:

$$
\log \gamma_{i}=-A z_{i}^{2} \sqrt{I}\left(1_{i}+B a ̊ \sqrt{I}\right),
$$

where $A$ and $B$ refer to the Debye-Hückel electrostatic parameters and were taken from Helgeson and Kirkham (1974), $I$ is the molal ionic strength, $z_{i}$ and $\stackrel{\circ}{i}_{i}$ represent the ionic charge and the distance of the closest approach for $i$ th species, respectively. We adopted a value for $\stackrel{\circ}{i}_{i}$ of $4.5 \AA$ for all charged species.

\subsection{Calculation of the Thermodynamic Properties of Arsenopyrite}

Arsenic aqueous concentrations measured in solution in equilibrium with the arsenopyrite-pyrite-pyrrhotite-magnetite assemblage allow calculation of the equilibrium constant of the following reaction, provided that the fugacities of $\mathrm{H}_{2}(\mathrm{~g})\left(f_{\mathrm{H}_{2}}\right)$ and $\mathrm{H}_{2} \mathrm{~S}(\mathrm{~g})\left(f_{\mathrm{H}_{2} \mathrm{~S}}\right)$ buffered by the PyPoMt assemblage are known:

$$
\begin{aligned}
\mathrm{FeAs}_{0.97} \mathrm{~S}_{1.07}+4.242 \mathrm{H}_{2} \mathrm{O}= & 0.333 \mathrm{Fe}_{3} \mathrm{O}_{4}+0.97 \mathrm{As}(\mathrm{OH})_{3}^{0}(\mathrm{aq}) \\
& +1.07 \mathrm{H}_{2} \mathrm{~S}(\mathrm{~g})+1.717 \mathrm{H}_{2}(\mathrm{~g})
\end{aligned}
$$

Note that analogous reactions can be written with pyrite or pyrrhotite. However, the thermodynamic properties of these phases are less constrained than those of magnetite. The chemical composition of the iron sulfides can also exhibit some variations (see above). Therefore, to avoid possible uncertainties related to the thermodynamic properties and stoichiometry of the iron sulfide phases, in the following calculations, we chose Eqn. 6 with stoichiometric magnetite, whose thermodynamic properties are at present precisely known (Hemingway, 1990).

The fugacities of $\mathrm{H}_{2}$ and $\mathrm{H}_{2} \mathrm{~S}$ were adopted from the study of Kishima (1989), who measured $f_{\mathrm{H}_{2}}$ and $f_{\mathrm{H}_{2} \mathrm{~S}}$ in aqueous solution in equilibrium with PyPoMt at 300 to $500^{\circ} \mathrm{C}$ and pressures below 1 kbar. These data constitute at present the most reliable and accurate data set on the PyPoMt buffer at hydrothermal conditions (Gibert et al., 1998). Values of $f_{\mathrm{H}_{2}}$ and $f_{\mathrm{H}_{2} \mathrm{~S}}$ derived by Kishima (1989) are in good agreement with those calculated using the SUPCRT92 database (Johnson et al., 1992) and assuming an activity of 0.5 for the FeS component in pyrrhotite (Toulmin and Barton, 1964; Gibert et al., 1998) and those generated by the GIBBS package and using a different set of the thermodynamic properties for $\mathrm{Fe}_{0.88} \mathrm{~S}$ (Shvarov and Bastrakov, 1999). A detailed comparison of $f_{\mathrm{H}_{2}}$ and $f_{\mathrm{S}_{2}} / f_{\mathrm{H}_{2} \mathrm{~S}}$ values in the system $\mathrm{Py}-\mathrm{Po}( \pm \mathrm{Mt})$ from older studies was given by Gibert et al. (1998). This comparison demonstrated that the maximal uncertainties on the values of $f_{\mathrm{H}_{2}}$ and $f_{\mathrm{H}_{2} \mathrm{~S}}$ in equilibrium with the PyPoMt assemblage in the temperature range 300 to $450^{\circ} \mathrm{C}$ and below $1 \mathrm{kbar}$ do not exceed \pm 0.05 and $\pm 0.1 \log$ unit, respectively.

Arsenic average molality at each temperature measured in this study in equilibrium with FeAsS-PyPoMt, $f_{\mathrm{H}_{2}}$ and $f_{\mathrm{H}_{2} \mathrm{~S}}$ adopted as discussed above, and the equilibrium constants derived for reaction 6 are reported in Table 3 together with their corresponding uncertainties. In Figure 4, the equilibrium constants generated in this study are compared, as a function of temperature at 500 bar, with those calculated using available thermodynamic data for the constituents of Eqn. 6 from Table 4. In these calculations, the Gibbs free energy of arsenopyrite was taken from Barton (1969), and the same reaction stoichiometry (Eqn. 6) was assumed for arsenopyrite dissolution for consistency. It can be seen that the calculated constants are 1 to 2 orders of magnitude higher than those measured in our study. This systematic discrepancy cannot be explained by the uncer- 
Table 3. Average arsenic concentrations in solution, $\mathrm{H}_{2}$ and $\mathrm{H}_{2} \mathrm{~S}$ fugacities in equilibrium with the arsenopyrite-pyrite-pyrrhotite-magnetite assemblage, equilibrium constants of reaction 6, and calculated apparent standard molal Gibbs free energies of arsenopyrite at each temperature and extrapolated to $25^{\circ} \mathrm{C}$ and 1 bar.

\begin{tabular}{lcccccccc}
\hline $\begin{array}{c}T \\
\left({ }^{\circ} \mathrm{C}\right)\end{array}$ & $\mathrm{P}(\mathrm{bar})$ & $\mathrm{As}^{\mathrm{a}}(\mathrm{mol} / \mathrm{kg})$ & $\log m_{\mathrm{As}}{ }^{\mathrm{a}}$ & $\log f_{\mathrm{H}_{2}}{ }^{\mathrm{b}}$ & $\log f_{\mathrm{H}_{2} \mathrm{~S}} \mathrm{~b}$ & $\log K_{6}$ & $\begin{array}{c}\Delta G_{P, T}{ }^{\mathrm{b}} \mathrm{FeAsS} \\
(\mathrm{kJ} / \mathrm{mol})\end{array}$ & $\begin{array}{c}\Delta_{f} G_{1298}{ }^{\mathrm{d}} \mathrm{FeAsS} \\
(\mathrm{kJ} / \mathrm{mol})\end{array}$ \\
\hline 300 & 400 & $0.00062 \pm 0.0002$ & $-3.21 \pm 0.15$ & -1.06 & -0.96 & $-5.96 \pm 0.25$ & -163.6 \\
350 & 500 & $0.0055 \pm 0.0010$ & $-2.26 \pm 0.08$ & -1.01 & -0.52 & $-4.48 \pm 0.15$ & -172.3 & $-138.7 \pm 3$ \\
400 & 500 & $0.07 \pm 0.01$ & $-1.15 \pm 0.07$ & -1.00 & -0.19 & $-3.04 \pm 0.15$ & -178.1 & $-141.7 \pm 4$ \\
450 & 500 & $0.32 \pm 0.03$ & $-0.50 \pm 0.05$ & -1.02 & 0.07 & $-2.16 \pm 0.15$ & -188.4 \\
$\pm 5^{\circ} \mathrm{C}$ & \pm 50 bar & & & $\pm 0.05 \log$ & $\pm 0.10 \log$ & & $\Delta_{f} G^{0}$ mean $=-141.6 \pm 6.9 \pm 7$ \\
\hline
\end{tabular}

${ }^{a}$ Average value from the runs shown in bold, italic type in Table 2 at each corresponding temperature.

${ }^{\mathrm{b}}$ According to Kishima (1989).

${ }^{c}$ From $\log K_{6}$ and the thermodynamic properties of the components of Eqn. 6 reported in Table 4 and using Eqn. 7 to correct for the nonstoichiometry of arsenopyrite.

${ }^{\mathrm{d}}$ Extrapolation to $25^{\circ} \mathrm{C}$ and 1 bar using $\mathrm{S}_{298}^{0}(\mathrm{FeAsS})$ and $C_{p}^{0}$ equation (Pashinkin et al., 1989) and $V^{0}$ (FeAsS) (Naumov et al., 1974) (see Table 5).

tainties associated with the free energies of magnetite, water, $\mathrm{H}_{2}(\mathrm{~g})$, and $\mathrm{H}_{2} \mathrm{~S}(\mathrm{~g})$, which do not exceed $\pm 0.5 \mathrm{~kJ} / \mathrm{mol}$. Gibbs free energies for $\mathrm{As}(\mathrm{OH})_{3}(\mathrm{aq})$ are also reasonably constrained to about \pm 3 to $4 \mathrm{~kJ} / \mathrm{mol}$ to at least $350^{\circ} \mathrm{C}$ (Pokrovski et al., 1996), which could correspond to $< \pm 0.3 \log$ unit variation of $\log K_{6}$. Moreover, equilibrium calculations using the available data for As sulfide aqueous complexes (Mironova et al., 1990; Webster, 1990; Eary, 1992; Helz et al., 1995), and $\mathrm{As}^{\circ}(\mathrm{aq})$ and $\mathrm{H}_{3} \mathrm{As}^{\mathrm{O}}(\mathrm{aq})$ (Sergeeva and Khodakovsky, 1969) indicate that all these species are negligible at conditions of our study. Our recent in situ extended X-ray absorption fine structure spectroscopy measurements demonstrated that the $\mathrm{As}(\mathrm{OH})_{3}^{0}(\mathrm{aq})$ complex is the only species existing in aqueous solution in the temperature range 25 to $500^{\circ} \mathrm{C}$ and pressures from 250 to 1000

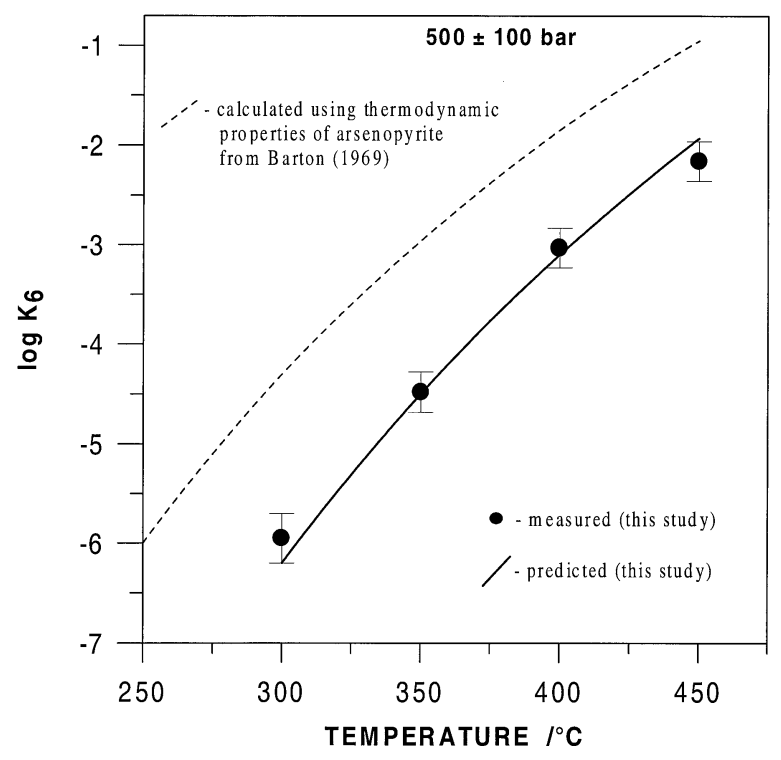

Fig. 4. Decimal logarithm of arsenopyrite dissolution reaction (Eqn. 6) constant as a function of temperature at 500 bar. The symbols were generated from FeAsS solubility experiments performed in this study in the presence of the pyrite-pyrrhotite-magnetite buffer. The curves were retrieved using the thermodynamic parameters of reaction constituents reported in Table 4 together with those of arsenopyrite generated in this study (solid curve) and those reported by Barton (1969) (dashed curve). bar at As concentrations below 1 mol (Pokrovski et al., 2002). These data confirm again that aqueous total As concentrations measured in the present study correspond to the $\mathrm{As}(\mathrm{OH})_{3}^{0}(\mathrm{aq})$ species formed according to Eqn. 6 in the entire temperatureconcentration range studied. As a result, the discrepancy between measured and calculated $K_{6}$ values in Figure 4 can be explained only by a lower (more negative) value of the Gibbs free energy of arsenopyrite than that presently available (Barton, 1969).

The Gibbs free energies of $\mathrm{FeAs}_{0.97} \mathrm{~S}_{1.07}$ at each experimental temperature and pressure were calculated from the equilibrium constant of Eqn. 6 derived in this study and the thermodynamic properties of the reaction constituents reported in Table 4. The corresponding values for a hypothetical stoichiometric arsenopyrite FeAsS (Table 3) were estimated assuming ideal behavior of As and S in arsenopyrite (Barton, 1969; Pashinkin et al., 1989):

$$
\begin{array}{rl}
G^{0}(\mathrm{FeAsS})=G^{0}\left(\mathrm{FeAs}_{0.97} \mathrm{~S}_{1.07}\right)-2.3026 R & T(\log 0.97 \\
& +\log 1.07)
\end{array}
$$

where $R$ is the ideal gas constant, and $T$ is temperature in $\mathrm{K}$. These corrections do not, however, exceed $0.2 \mathrm{~kJ} / \mathrm{mol}$. Such a minor difference for the free energy of slightly nonstoichiometric arsenopyrite is in agreement with a regular As-S substitution and a free-defect FeAsS structure (Barton, 1969; Fuess et al., 1987) and in the limit of the uncertainties for the stability fields in the system Fe-As-S involving arsenopyrite of variable As/S composition (Kretschmar and Scott, 1976). The values of $\Delta G_{P, T}^{0}(\mathrm{FeAsS})$ derived in this study at $300^{\circ} \mathrm{C}$ and $400 \mathrm{bar}$ and at $350,400,450^{\circ} \mathrm{C}$ and 500 bar were extrapolated to $25^{\circ} \mathrm{C}$ and 1 bar using the molal volume of FeAsS (Naumov et al., 1974) and the recently available FeAsS heat capacity $\left(C_{p}\right)$ MaierKelley (Maier and Kelley, 1932) equation from 25 to $350^{\circ} \mathrm{C}$ and standard entropy at $25^{\circ} \mathrm{C}$ (Pashinkin et al., 1989). Because heat capacities of most solids usually exhibit a regular behavior with temperature, which can be accurately described by a three-term Maier-Kelley equation, we assumed that the $C_{p}$ equation of Pashinkin et al. (1989) could be used at temperatures from 800 to $900^{\circ} \mathrm{C}$ without introducing significant errors (> $\pm 5 \mathrm{~kJ} / \mathrm{mol}$ for $\Delta G_{\mathrm{FeAsS}}^{0}$ at $T>600^{\circ} \mathrm{C}$ ). The arithmetic average of $\Delta_{f} \mathrm{G}_{1,298}$ (FeAsS) values obtained by the above 
Table 4. Thermodynamic parameters of solids, gases, and aqueous species used for calculation of the Gibbs free energy of arsenopyrite.

\begin{tabular}{|c|c|c|c|c|}
\hline Substance & $\begin{array}{l}\Delta_{f} G_{1,298}^{0} \\
(\mathrm{~kJ} / \mathrm{mol})\end{array}$ & $\begin{array}{c}S_{1,298}^{0} \\
(\mathrm{~J} / \mathrm{mol} \mathrm{K})\end{array}$ & $\begin{array}{c}V_{1,298}^{0} \\
\left(\mathrm{~cm}^{3} / \mathrm{mol}\right)\end{array}$ & Heat capacity equation $(\mathrm{J} / \mathrm{mol} \mathrm{K})$ (high-temperature limit, $\mathrm{K}$ ) \\
\hline Solids & & & & \\
\hline $\begin{array}{l}\text { Magnetite } \\
\mathrm{Fe}_{3} \mathrm{O}_{4}{ }^{\mathrm{a}}\end{array}$ & -1012.57 & 146.14 & 44.7 & $2569.1-2.5215 T+20.734 \times 10^{6} T^{-2}-36.4655 \times 10^{-3} T^{-0.5}+1.3677 \times 10^{-3} T^{2}(800 \mathrm{~K})$ \\
\hline Gases & & & & \\
\hline $\mathrm{H}_{2}(\mathrm{~g})^{\mathrm{b}}$ & 0 & 130.680 & & $7.4424+0.011707 T-5.1041 \times 10^{5} T^{-2}+410.17 T^{-0.5}-1.3899 \times 10^{-6} T^{2}(1800 \mathrm{~K})$ \\
\hline $\mathrm{H}_{2} \mathrm{~S}(\mathrm{~g})^{\mathrm{b}}$ & -33.431 & 205.670 & - & $26.356+0.0265 T+2.66 \times 10^{5} T^{-2}-43.559 T^{-0.5}-6.0244 \times 10^{-6} T^{2}(1800 \mathrm{~K})$ \\
\hline $\begin{array}{l}\text { Aqueous species } \\
\mathrm{As}(\mathrm{OH})_{3}{ }^{{ }_{0}}\end{array}$ & -639.78 & 200.0 & 49.0 & $\begin{array}{l}\text { HKF parameters (joule units) } \\
a_{1} \times 10=35.44 ; a_{2} \times 10^{-2}=53.97 ; a_{3}=2.85 ; a_{4} \times 10^{-4}=-13.85 ; c_{1}=209.2 ; c_{2} \times \\
10^{-4}=-6.28 ; \omega=0\end{array}$ \\
\hline
\end{tabular}

${ }^{a}$ Hemingway (1990).

${ }^{\text {b}}$ Robie et al. (1978).

'Pokrovski et al. (1996).

extrapolation (Table 3) was taken as the recommended standard Gibbs free energy of formation of arsenopyrite at $25^{\circ} \mathrm{C}$ and 1 bar: $\Delta_{f} \mathrm{G}_{1,298}^{0}(\mathrm{FeAsS})=-141.6 \pm 6 \mathrm{~kJ} / \mathrm{mol}$. The uncertainty on this value stems mainly from those associated with $\log K_{6}$ (Table 3, see above), Gibbs free energy extrapolations from high temperature $\left(>400^{\circ} \mathrm{C}\right)$ using the adopted $C_{p}^{0}$ (FeAsS) equation, and $\mathrm{As}(\mathrm{OH})_{3}^{0}(\mathrm{aq})$ Gibbs free energy above $350^{\circ} \mathrm{C}$. The thermodynamic properties of the $\mathrm{As}(\mathrm{OH})_{3}{ }^{\mathrm{O}}(\mathrm{aq})$ species that have been generated using the Helgeson-Kirkham-Flowers (HKF) model (Helgeson et al., 1981) on the basis of $\mathrm{As}_{2} \mathrm{O}_{3}$ and $\mathrm{As}_{2} \mathrm{~S}_{3}$ solubility data to $300^{\circ} \mathrm{C}$ (Pokrovski et al., 1996) and in the absence of direct high-temperature measurements on $C_{p}{ }^{0}$ and $V^{0}$ of arsenious acid could exhibit large uncertainties above 350 to $400^{\circ} \mathrm{C}(>5 \mathrm{~kJ} / \mathrm{mol})$. Thus, the FeAsS Gibbs free energies obtained in this study at temperatures above $400^{\circ} \mathrm{C}$ would be better constrained when such $C_{p}$ and $V$ data become available, which is a subject of our future work.

The thermodynamic properties of FeAsS adopted in this study together with those available in the literature are summarized in Table 5, and apparent standard molal Gibbs free energies of arsenopyrite calculated using these parameters are plotted in Figure 5 as a function of temperature at 1 bar. It can be seen in the table and figure that the Gibbs free energy values of FeAsS obtained from phase equilibria at high temperature in the system Fe-As-S (Barton, 1969) or As vapor pressure mea- surements over FeAsS (Zviadadze and Rtskhiladze, 1964; Pashinkin et al., 1979) are very different from one another and significantly higher (more positive) than those obtained in this study. The highest existing $\Delta_{f} G_{1,298}(\mathrm{FeAsS})$ values (Zviadadze and Rtskhiladze, 1964; Wagman et al., 1982) seem to be in error, because they imply an extremely low arsenopyrite stability, inconsistent with high-temperature phase equilibria (Clark, 1960; Barton, 1969) and arsenopyrite stability and solubility in aqueous solution (Kolonin et al., 1989; Pal'yanova and Kolonin, 1992; this study). The values of the standard entropy of FeAsS cited by Zviadadze and Rtskhiladze (1964) and Wagman et al. (1982) and that derived by Barton (1969) are also higher by a factor of 1.5 than the corresponding value obtained from the direct measurements of FeAsS heat capacity from 5 to $620 \mathrm{~K}$ (Pashinkin et al., 1989). Note that a similar difference exists between the standard entropy of loellingite obtained from low-temperature $C_{p}$ measurements $\left(\mathrm{S}^{\mathrm{O}}{ }_{298}\left(\mathrm{FeAs}_{2}\right)=80.06 \mathrm{~J} / \mathrm{mol} \mathrm{K}\right.$; Pashinkin et al., 1991) and the corresponding value extrapolated from high-temperature $\left(>600^{\circ} \mathrm{C}\right)$ phase equilibria data $\left(\mathrm{S}_{298}^{0}\left(\mathrm{FeAs}_{2}\right)=127.2 \mathrm{~J} / \mathrm{mol}\right.$ $\mathrm{K}$; Barton, 1969). This discrepancy is likely to stem from such high-temperature extrapolations, which could have significant uncertainties. Thus, the $\mathrm{S}_{298}{ }_{298}$ and $C_{p}{ }^{\mathrm{O}}(T)$ values of FeAsS generated by Pashinkin et al. (1989) are likely to be more reliable and, therefore, were adopted in the present study. It can

Table 5. Standard thermodynamic properties of arsenopyrite available in the literature and generated in this study.

\begin{tabular}{|c|c|c|c|c|}
\hline $\begin{array}{l}\Delta_{f} G_{1,298}^{0} \\
(\mathrm{~kJ} / \mathrm{mol})\end{array}$ & $\begin{array}{c}S_{1,298}^{0} \\
(\mathrm{~J} / \mathrm{mol} \mathrm{K})\end{array}$ & $\begin{array}{c}V_{1,298}^{0} \\
\left(\mathrm{~cm}^{3} / \mathrm{mol}\right)\end{array}$ & $\begin{array}{c}C_{p 1,298}^{0} \\
(\mathrm{~J} / \mathrm{mol} \mathrm{K})\end{array}$ & $\begin{array}{l}\text { Heat capacity equation }(\mathrm{J} / \mathrm{mol} \mathrm{K} \text { ) (high-temperature } \\
\text { limit, K) }\end{array}$ \\
\hline$-109.6^{\mathrm{a}}$ & $108.4^{\mathrm{a}}$ & - & - & - \\
\hline$-112.1^{\mathrm{b}}$ & $115.5^{\mathrm{b}}$ & - & - & - \\
\hline$-42.0^{\mathrm{c}}$ & $102.9^{\mathrm{c}}$ & - & $73.4^{\mathrm{d}}$ & $62.89+40.58 \times 10^{-3} T-1.423 \times 10^{5} T^{-2}(993 \mathrm{~K})^{\mathrm{d}}$ \\
\hline$-50.0^{\mathrm{e}}$ & $121.0^{\mathrm{e}}$ & - & - & - \\
\hline$-141.6 \pm 6.0^{\mathrm{f}}$ & $68.5 \pm 0.9^{g}$ & $26.42^{\mathrm{h}}$ & $68.44^{\mathrm{g}}$ & $75.51+4.78 \times 10^{-3} \mathrm{~T}-7.543 \times 10^{5} \mathrm{~T}^{-2}(900 \mathrm{~K})^{\mathrm{g}}$ \\
\hline
\end{tabular}

${ }^{a}$ Barton (1969): extrapolation to $25^{\circ} \mathrm{C}$ using data on phase equilibria in the system $\mathrm{Fe}-\mathrm{As}-\mathrm{S}$ at 500 to $800^{\circ} \mathrm{C}$.

bPashinkin et al. (1979): extrapolation to $25^{\circ} \mathrm{C}$ using measurements of As vapor pressure during the thermal dissociation of $\mathrm{FeAsS}$ at 600 to $700^{\circ} \mathrm{C}$.

'Zviadadze and Rtskhiladze (1964): extrapolation to $25^{\circ} \mathrm{C}$ from measurements of As vapor pressure during thermal dissociation of FeAsS at 600 to $830^{\circ} \mathrm{C}$.

dZviadadze and Rtskhiladze (1964): empirical heat capacity equation, corrected by Naumov et al. (1974).

${ }^{\text {e}}$ Wagman et al. (1982): unknown source.

fThis study: solubility of FeAsS in aqueous solution from 300 to $450^{\circ} \mathrm{C}$ and in the presence of PyPoMt.

${ }^{\mathrm{g}}$ Pashinkin et al. (1989): heat capacity measurements of FeAsS (5 to $650 \mathrm{~K}$ ).

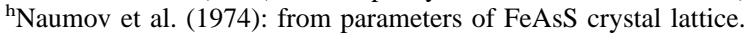




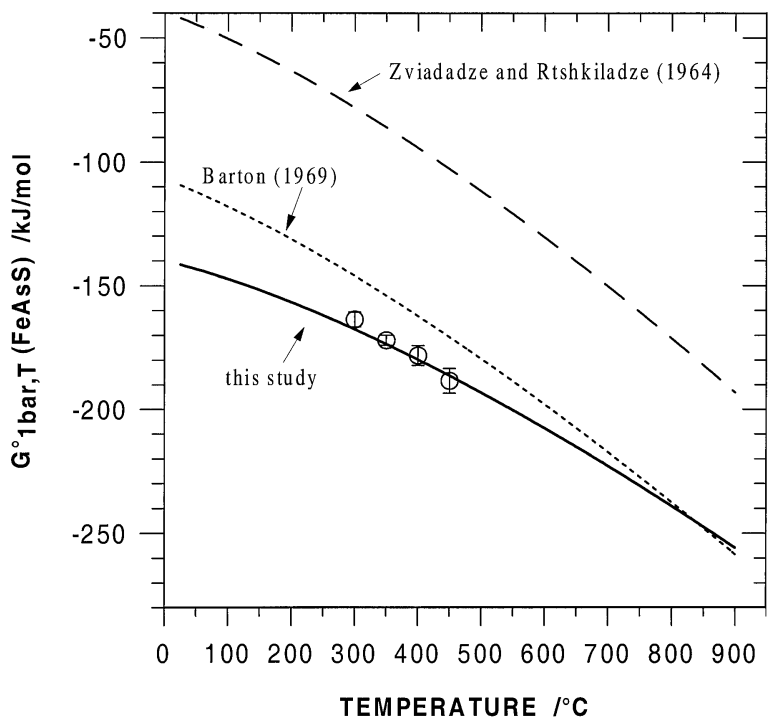

Fig. 5. Plot of the apparent standard molal Gibbs free energies of stoichiometric arsenopyrite (FeAsS) as a function of temperature at 1 bar. The symbols stand for the experimental data obtained in this study, and the curves were generated using thermodynamic parameters of arsenopyrite from the references reported in this figure and Table 5.

be seen in Fig. 5 that at low temperatures, the values of $\Delta G^{0}{ }_{1, T}$ (FeAsS) generated in our study are 30 to $20 \mathrm{~kJ} / \mathrm{mol}$ more negative than those of Barton (1969), but above $600^{\circ} \mathrm{C}$, both sets of data are in agreement within $10 \mathrm{~kJ} / \mathrm{mol}$.

\subsection{Interpretation of FeAsS Solubilities and Mineral Parageneses in Nonbuffered Aqueous Solutions}

The thermodynamic parameters of FeAsS generated in this study were used to calculate arsenopyrite solubility and stability in nonbuffered aqueous solutions and to compare these results with our experimental measurements. These calculations were performed using the GIBBS computer code (Shvarov and Bastrakov, 1999), consistent with the revised HKF equation of state (Tanger and Helgeson, 1988). Thermodynamic properties of native As, iron sulfides $\left(\mathrm{FeS}_{2}, \mathrm{FeS}\right)$, and magnetite were taken from the IVTANTHERMO database (Shvarov and Bastrakov, 1999) and Hemingway (1990), respectively. Those for iron arsenides, $\mathrm{FeAs}_{2}$ (lollingite), and FeAs (vesterveldite) were supplied by Khodakovsky (personal communication) and are based on direct enthalpy and heatcapacity calorimetric measurements (Stolyarova, 1977; Gonzalez-Alvarez et al., 1989; Pashinkin et al., 1991). Thermodynamic parameters for water and aqueous species $\left(\mathrm{Na}^{+}, \mathrm{Cl}^{-}\right.$, $\mathrm{NaCl}^{\circ}(\mathrm{aq}), \mathrm{H}^{+}, \mathrm{OH}^{-}, \mathrm{H}_{2}{ }^{\mathrm{O}}(\mathrm{aq}), \mathrm{H}_{2} \mathrm{~S}^{\mathrm{O}}(\mathrm{aq})$, and $\mathrm{HS}^{-}$) were adopted from the SUPCRT92 database (Johnson et al., 1992), and those for $\mathrm{As}(\mathrm{OH})_{3}{ }^{\mathrm{O}}(\mathrm{aq})$ and $\mathrm{AsO}(\mathrm{OH})_{2}{ }^{-}$are from Pokrovski et al. (1996) and Pokrovski (1996), respectively. HKF parameters for $\mathrm{Fe}$ hydroxide and chloride complexes were taken from Shock et al. (1997) and Sverjensky et al. (1997), respectively, whereas those for $\mathrm{HCl}^{\mathrm{O}}(\mathrm{aq})$ and $\mathrm{NaOH}^{\mathrm{O}}(\mathrm{aq})$ were adopted from Tagirov et al. (1997) and Shock et al. (1997), respectively. The stability of $\mathrm{NaHS}^{0}(\mathrm{aq})$ was assumed to be equal to that of $\mathrm{NaOH}^{\mathrm{O}}(\mathrm{aq})$.

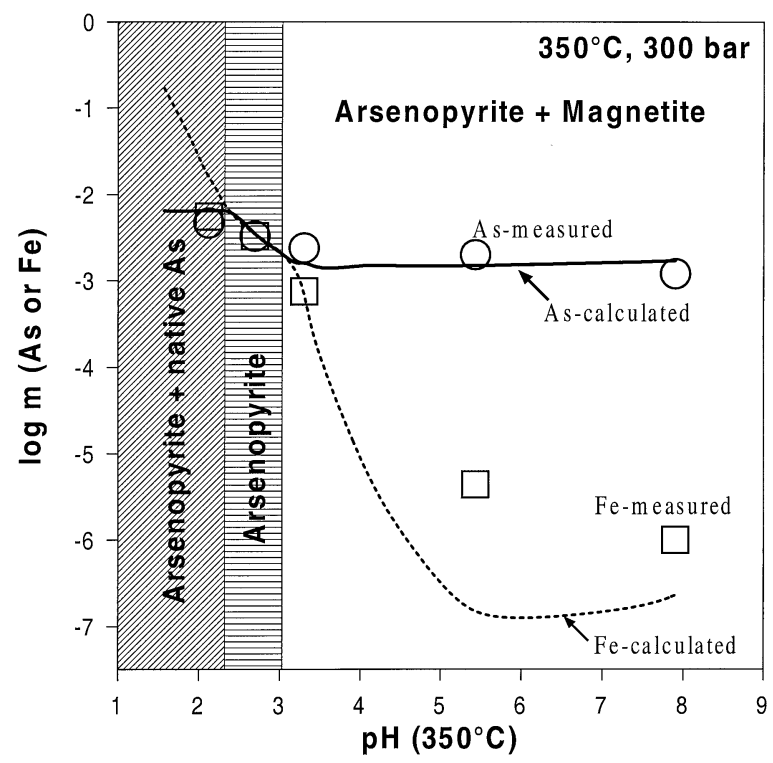

Fig. 6. Arsenic and iron steady-state concentrations in aqueous solution and observed mineral stability fields in the system arsenopyrite- $\mathrm{H}_{2} \mathrm{O} \pm \mathrm{HCl} \pm \mathrm{NaOH}$ as a function of $\mathrm{pH}$ at $350^{\circ} \mathrm{C}$ and 300 bar. The symbols represent aqueous As (circles) and Fe (squares) average concentrations at steady state measured in this study. The curves denote aqueous As (solid curve) and $\mathrm{Fe}$ (dashed curve) concentrations calculated using the thermodynamic parameters of FeAsS generated in this study and assuming an equilibrium between solution and the mineral assemblages depicted in the figure.

In Fig. 6, stability fields of minerals formed in equilibrium with arsenopyrite, together with $\mathrm{As}$ and $\mathrm{Fe}$ concentrations in solution, are calculated as a function of $\mathrm{pH}$ (imposed by $\mathrm{HCl}$ concentration) at $350^{\circ} \mathrm{C}$ and 300 bar. It can be seen that both mineral parageneses predicted as a function of $\mathrm{pH}$ and As aqueous concentrations calculated using the value of FeAsS free energy derived in our study from independent measurements (section 4.2) are in excellent agreement with our experiments (see section 3.1). With increasing $\mathrm{pH}$, the following mineral sequence is observed: arsenopyrite + arsenic - arsenopyrite - arsenopyrite + magnetite. No $\mathrm{FeAs}_{2}$ or FeAs phases in equilibrium with arsenopyrite were predicted by calculations, confirming that the observed erratic FeAsS nearsurface enrichment by As most probably reflects the dissolution kinetics and is not an equilibrium process (see section 3.1). The measured arsenic concentrations in equilibrium with the $\mathrm{FeAsS}-\mathrm{Fe}_{3} \mathrm{O}_{4}$ assemblage in pure water and dilute $\mathrm{HCl}$ solutions at different temperatures are also in good agreement with the calculated values (Fig. 7). Arsenic concentrations in pure water measured in our study at $350^{\circ} \mathrm{C}$ and 300 bar are close to the corresponding values at 500 bar reported by Pal'yanova and Kolonin (1992). In contrast, As concentrations measured by Kolonin et al. (1989) in analogous solutions at $300^{\circ} \mathrm{C}$ are higher by a factor of 5 than those predicted in the present study. Possible oxidation of As and $\mathrm{H}_{2} \mathrm{~S}$, which was likely to be not controlled in their experiments, could shift the Eqn. 1 equilibrium to the right side and thus account for the elevated As and $\mathrm{S}$ concentrations measured in their study. Arsenic concentrations and mineral associations found in our runs carried out with excess $\mathrm{H}_{2} \mathrm{~S}$ and $\mathrm{H}_{2}$ (Table 1; section 3.1) are in qualitative 


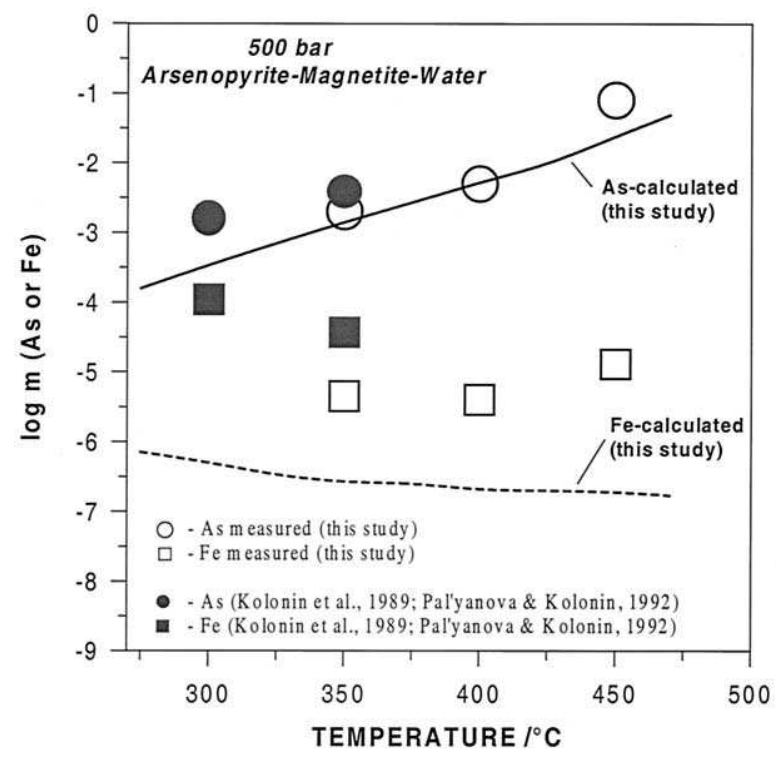

Fig. 7. Decimal logarithms of As and Fe concentrations in pure water in equilibrium with the arsenopyrite-magnetite assemblage as a function of temperature. The symbols depict experimental data from the present study and taken from the literature at 500 bar (except the data point from this study at $350^{\circ} \mathrm{C}$, which was measured at 300 bar). The curves were calculated at 500 bar using the available thermodynamic parameters for magnetite and aqueous species in the system FeAsS$\mathrm{H}_{2} \mathrm{O}$ (see text) and those for arsenopyrite generated in this study (Table $5)$.

agreement with the calculations, which predict arsenopyritepyrrhotite $( \pm$ pyrite $)$ and arsenopyrite-loellingite $( \pm$ magnetite) assemblages in $\mathrm{H}_{2} \mathrm{~S}$-rich and $\mathrm{H}_{2}$-rich solutions, respectively.

Measured and calculated iron concentrations at acid $\mathrm{pH}$ in $\mathrm{HCl}$ solutions at different temperatures are in good agreement (Fig. 6) and consistent with the predominance of $\mathrm{Fe}^{2+}, \mathrm{FeCl}^{+}$, and $\mathrm{FeCl}_{2}^{\mathrm{O}}(\mathrm{aq})$ complexes, depending on $\mathrm{HCl}$ concentration. At neutral $\mathrm{pH}$, however, the measured concentrations are 1 to 2 orders of magnitude higher than the predictions. The same discrepancy between calculated and measured Fe contents was found in the present study and previous works at different temperatures in pure water (Fig. 7), and in our experiments with pyrite-pyrrhotite-magnetite (not shown). Such a discrepancy could arise from the uncertainties both on the thermodynamic data for $\mathrm{Fe}(\mathrm{II})$-hydroxide complexes and $\mathrm{pH}$ values in the nonbuffered near-neutral solutions. The higher measured $\mathrm{Fe}$ concentrations in solutions with significant As content ( $>1$ to 2 $\mathrm{mmol}$ ), could also suggest the existence of $\mathrm{Fe}(\mathrm{II})$-arsenite aqueous complexes, which might be important in the absence of other iron-complexing ligands $\left(\mathrm{Cl}^{-}\right)$at neutral $\mathrm{pH}$. More measurements at controlled $\mathrm{pH}$ and $f_{\mathrm{O}_{2}}$ and as a function of As content are necessary to unambiguously interpret iron speciation in these As-bearing neutral solutions.

\section{INTERPRETATION OF ARSENOPYRITE FORMATION AND ARSENIC CONCENTRATIONS IN CRUSTAL FLUIDS}

The thermodynamic properties of arsenopyrite derived in this study can be used to better understand FeAsS formation conditions and quantitatively interpret As concentrations observed in high-temperature crustal fluids in the presence of this

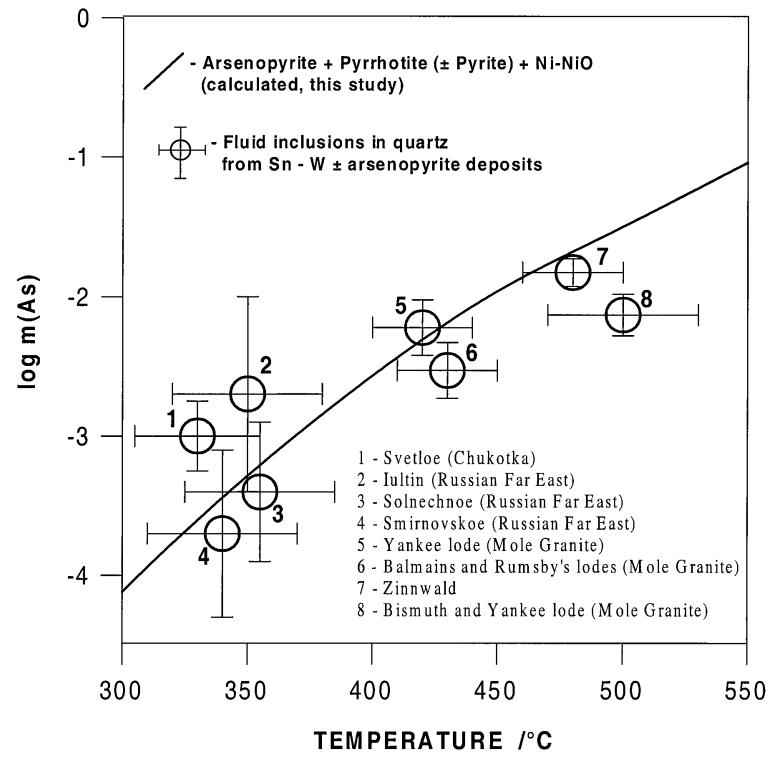

Fig. 8. Comparison between measured and predicted arsenic concentrations in high-temperature magmatic-hydrothermal fluids. The symbols stand for literature data on As contents and homogenization temperatures measured on fluid inclusions in quartz from cassiteritewolframite \pm arsenopyrite deposits indicated by numbers in the figure with the following mineral assemblages: (1) quartz-topaz-cassiterite \pm arsenopyrite, (2) quartz-chalcopyrite-wolframite-cassiterite \pm arsenopyrite, (3) quartz-cassiterite-arsenopyrite-tourmaline-pyrite-chalcopyrite, (4) quartz-cassiterite-arsenopyrite (Sushchevskaya et al., 1993), (5) quartz-cassiterite-muscovite (Heinrich et al., 1992), (6) quartz-wolframite-muscovite \pm arsenopyrite \pm pyrrhotite (Audédat et al., 2000), (7) quartz-cassiterite-wolframite (Heinrich et al., 1999), and (8) quartz-cassiterite-K-feldspar (Audédat et al., 2000). The solid curve was calculated for 500 bar assuming equilibrium between a 2- $m$ $\mathrm{NaCl}$ fluid and the arsenopyrite-pyrrhotite ( \pm pyrite) assemblage at oxygen fugacities fixed by $\mathrm{Ni}-\mathrm{NiO}$ and using arsenopyrite thermodynamic properties generated in the present study (see text for explanation).

mineral. Results of mineral-fluid equilibrium calculations performed using these new data are compared below with arsenic behavior in magmatic-hydrothermal ore deposit environments and modern hydrothermal systems.

\subsection{Mineral Paragenesis and Fluid Inclusions From Magmatic-Hydrothermal W-Sn-Cu Ore Deposits}

Among sulfide and sulfo-arsenide minerals, arsenopyrite together with pyrite and pyrrhotite are the most abundant and commonly present in high-temperature $\left(>300^{\circ} \mathrm{C}\right) \mathrm{Sn}-, \mathrm{W}-$, Mo-, and $\mathrm{Cu}(+\mathrm{Au})-$ dominated hydrothermal deposits spatially related to mineralized granites and granitoids (Heinrich and Eadington, 1986; Sushchevskaya et al., 1993; Audédat et al., 2000). In Fig. 8, calculated arsenic concentrations in a 2-m $\mathrm{NaCl}$ solution in equilibrium with arsenopyrite-pyrrhotite ( \pm pyrite) assemblage are depicted as a function of temperature. The calculations were accomplished using the thermodynamic properties of FeAsS derived in this study and those for other minerals and aqueous species as discussed above. Oxygen fugacity was assumed to be buffered by the $\mathrm{Ni}-\mathrm{NiO}$ assemblage, which is close to equilibria involving $\mathrm{Fe}^{2+} / \mathrm{Fe}^{3+}$-bearing silicate and oxides (Wones, 1981; Kishima, 1989). At the high 
temperatures corresponding to the separation of metal-rich fluids from a large mass of granitic rocks, redox equilibria among host rock minerals, including Fe-silicates and Fe-Ti oxides, are likely to control the oxygen fugacity in the fluid-rock system of porphyry-style deposits (Heinrich and Eadington, 1986; Heinrich, 1990). The choice of pyrrhotite \pm pyrite as the minerals controlling sulfur fugacity in the fluid is in agreement with the mineral paragenesis arsenopyrite-pyrrhotite \pm pyrite observed in many Sn- and W-porphyry-style and vein-style deposits. Our calculations indicate that the arsenopyrite-pyrrhotite assemblage is stable over the range 300 to $500^{\circ} \mathrm{C}$, corresponding to the preore and ore formation stages, but pyrite appears only at temperatures lower than 400 to $450^{\circ} \mathrm{C}$. This is in qualitative agreement with the observed mineral precipitation sequence in several Sn and W deposits of Mole Granite (e.g., Taronda W deposit, Balman and Rumsby, and Yankee Lode Sn-deposits; Audédat et al., 2000) and quartz-cassiterite-wolframite-arsenopyrite veins of the Russian Far East (Sushchevskaya et al., 1993). Moreover, calculated $\mathrm{H}_{2} \mathrm{~S}$ solution concentrations in equilibrium with pyrrhotite \pm pyrite are in close agreement with those measured in fluid inclusions in quartz from these Russian deposits $\left(m_{\mathrm{H}_{2} \mathrm{~S}} \sim 0.01\right.$ to $0.001 \mathrm{~mol}$; Korsakova et al., 1991; Sushchevskaya et al., 1996). In Fig. 8 are also plotted arsenic concentrations recently measured in saline fluid inclusions hosted in quartz from different $\mathrm{Sn}, \mathrm{W}$, and $\mathrm{Cu}$ hightemperature $\left(>300^{\circ} \mathrm{C}\right)$ deposits containing arsenopyrite (Heinrich et al., 1992; Sushchevskaya et al., 1993; Heinrich et al., 1999; Audédat et al., 2000). It should be noted that vapor-brine separation phenomena were observed in some of these magmatic-hydrothermal deposits, which was demonstrated by the coexistence of inclusions containing low-density vapor and high-density $\mathrm{NaCl}$ brine (e.g., Audédat et al., 1998, 2000, and references therein; Heinrich et al., 1999). The present study uses only data on As contents measured in the high-density inclusions, in which As aqueous speciation can be reliably described by the $\mathrm{As}(\mathrm{OH})_{3}^{0}(\mathrm{aq})$ species in the framework of the HKF model (see above; Pokrovski et al., 1996). Interpretation of arsenic concentrations measured in vapor inclusions from these deposits will be proposed in a subsequent paper (Pokrovski et al., 2002).

It can be seen in Fig. 8 that the predicted As concentrations in equilibrium with arsenopyrite (solid line) are slightly higher than the As contents (symbols 6 to 8 ) measured in the $\mathrm{NaCl}$ rich fluid, which has been trapped by growing quartz in hightemperature $\left(>400^{\circ} \mathrm{C}\right)$ quartz-cassiterite-wolframite veins of Mole Granite and Zinnwald. This is in agreement with the scarcity of arsenopyrite and other sulfides in association with this fluid-trapping quartz generation. Regionally associated lower temperature veins in these ore fields contain, by contrast, important amounts of arsenopyrite and pyrrhotite \pm pyrite (Audédat et al., 2000). Thus, the higher calculated saturating As concentrations (line) than the measured As contents (symbols 6 to 8 ) in the high-temperature fluid inclusions from these deposits are consistent with geological observations that these fluids were undersaturated with respect to arsenopyrite. Arsenic concentrations derived from fluid inclusions in quartz from lower temperature $\left(<350^{\circ} \mathrm{C}\right)$ cassiterite-wolframite-arsenopyrite \pm pyrrhotite veins from deposits of the Russian Far East (symbols 1 to 4 in Fig. 8) are in agreement, in the limit of their uncertainties, to our predictions. This indicates that the equi- librium with arsenopyrite is likely to control As concentrations in these fluids. Note that similar calculations carried out with the previously proposed set of arsenopyrite thermodynamic properties (Barton, 1969; Naumov et al., 1974) either imply very high As concentrations (from 0.1 to $1 \mathrm{~mol}$ ) in equilibrium with FeAsS, incompatible with the natural observations, or would require oxygen fugacities for FeAsS formation much lower than $\mathrm{Ni}-\mathrm{NiO}$, which is inconsistent with the compositions of host rocks, fluids, and ore-mineral assemblages. By contrast, the higher stability of arsenopyrite obtained in the present study implies that this mineral is likely to precipitate with decreasing temperature from the exsolving fluid, which remains buffered with regard to oxygen fugacity by host granitic rocks throughout its cooling history.

\subsection{Arsenic Concentrations in Modern Hydrothermal Systems}

The most common As-bearing minerals found in epithermal deposits and modern low-temperature hydrothermal sources are orpiment or its amorphous analog $\left(\mathrm{As}_{2} \mathrm{~S}_{3}\right)$ and realgar (AsS) (Ballantine and Moore, 1988; Eary, 1992). At temperatures below $150^{\circ} \mathrm{C}$, these minerals have been shown to often control aqueous As concentrations in these environments (Pokrovski et al., 1996). In high-temperature $\left(T \geq 200^{\circ} \mathrm{C}\right)$ geothermal systems, these minerals are too soluble to be stable, and arsenic occurs predominantly in pyrite (Ballantine and Moore, 1988). Arsenic concentrations in pyrite from modern hydrothermal systems (e.g., Roosevelt Hot Springs, Salton Sea, Broadlands) were found to range from 0 to $4 \mathrm{wt} . \%$ (Ballantine and Moore, 1988, and references therein). The formation of As-bearing pyrite in the modern hydrothermal reservoirs was modeled using the results of our study and assuming that As in pyrite is present as arsenopyrite ideal solid solution. This assumption is dictated by the arsenic valence state of -1 found both in pyrite and arsenopyrite (Tossel et al., 1981; Fleet et al., 1989; Simon et al., 1999) and by the phase compositions in the system $\mathrm{Fe}-\mathrm{As}-\mathrm{S}$, in which up to $10 \mathrm{~mol} \%$ of $\mathrm{FeS}_{2}$ can occur in FeAsS or $\mathrm{FeAs}_{2}$ (Clark, 1960; Barton, 1969). Arsenic concentrations in solution in equilibrium with $\mathrm{Fe}(\mathrm{As}, \mathrm{S})_{2}$ were calculated adopting an average FeAsS mole fraction $(\approx$ activity) of 0.02 in pyrite and assuming an iron conserving equilibrium reaction between arsenopyrite and pyrite (Ballantine and Moore, 1988; Heinrich and Eadington, 1986):

$$
\begin{aligned}
\mathrm{FeAsS}+\mathrm{H}_{2} \mathrm{~S}(\mathrm{~g})+1.25 \mathrm{O}_{2}(\mathrm{~g})+0.5 \mathrm{H}_{2} \mathrm{O} & =\mathrm{FeS}_{2} \\
& +\mathrm{As}(\mathrm{OH})_{3}^{\mathrm{O}}(\mathrm{aq})
\end{aligned}
$$

In these calculations, oxygen fugacity was approximated by the equation of Kishima (1989): $\log f_{\mathrm{O}_{2}}=8.7-23,560 / T(\mathrm{~K}) \pm$ 1 , which corresponds to the typical redox conditions found in volcanic rock-water systems and is in good agreement with the oxygen fugacities estimated in modern hydrothermal systems (see Table 1 in Ballantine and Moore, 1988). Fugacity of $\mathrm{H}_{2} \mathrm{~S}$ and $\mathrm{pH}$ were fixed at 0.02 bar and 6 , respectively, which corresponds to their average values found in a variety of modern hydrothermal reservoirs (see Table 1 in Ballantine and Moore, 1988). In Fig. 9, calculated As concentrations are presented by the solid line together with possible uncertainties (dashed lines), which account for the variations of $f_{\mathrm{O}_{2}}$ and 


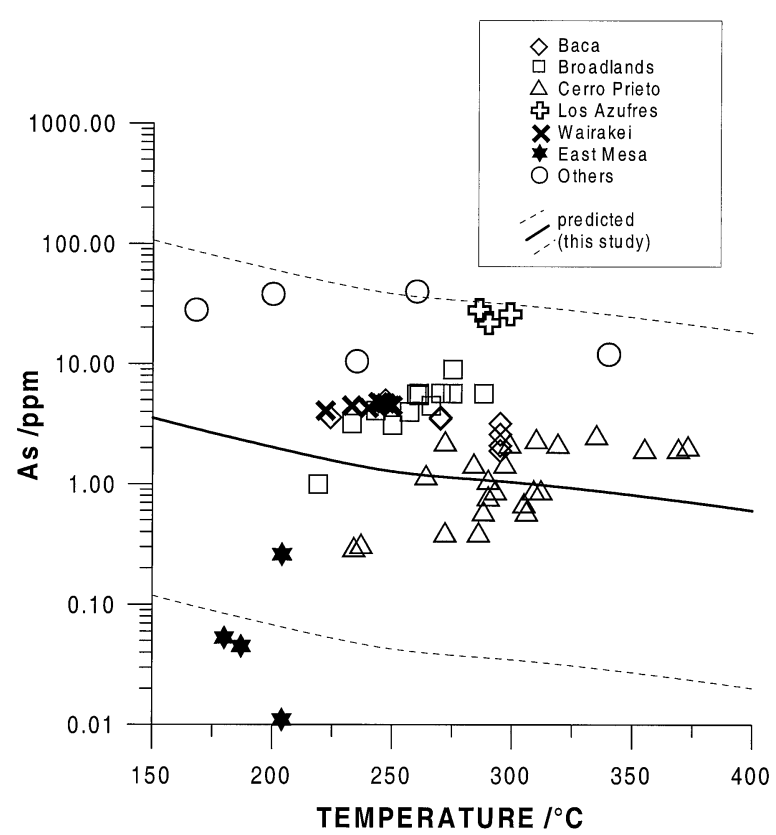

Fig. 9. Arsenic concentrations in modern hydrothermal fluids. The symbols depict As aqueous contents measured in modern hydrothermal sources cited in the figure (according to Ballantine and Moore, 1988). The solid line represents As fluid concentrations calculated, together with the corresponding uncertainties (dashed lines), in equilibrium with As-bearing pyrite commonly present in these systems (see text for details).

$f_{\mathrm{H}_{2} \mathrm{~S}}$ in the fluid and As content in pyrites for different reservoirs (see above and Ballantine and Moore, 1988). In can be seen in this figure that the predicted As concentrations are in agreement, in the limit of their uncertainties, with those measured in these hydrothermal fluids. Thus, As-bearing pyrite is likely to control As contents in modern hydrothermal solutions at temperatures above $150^{\circ} \mathrm{C}$.

\subsection{Arsenic-Gold Association in Meso- and Epithermal Sulfide Deposits}

In many meso- and epithermal deposits $\left(T<300^{\circ} \mathrm{C}\right)$, gold is found to be closely associated with arsenopyrite and/or arsenian pyrite (e.g., Boyle, 1979; Cathelineau et al., 1989; Arehart et al., 1993; Cabri et al., 2000). Both "visible" native gold in association with the sulfoarsenide minerals and "invisible" gold incorporated in these minerals occur. Despite ample discussion about the chemical form of $\mathrm{Au}$ and $\mathrm{Au}-\mathrm{As}$ structural relationships in arsenopyrite and As-pyrite, recent spectroscopic studies agree that "invisible" gold occurs in two chemical states: an elemental form as nanometer-size particles of $\mathrm{Au}^{0}$ and covalently bound gold with a still uncertain oxidation state between $\mathrm{Au}^{3+}$ and $\mathrm{Au}^{1-}$ (see Cabri et al., 2000, for review). Because gold is transported in sulfur-rich hydrothermal fluids as sulfide complexes of $\mathrm{Au}^{1+}\left(\mathrm{AuHS}^{\mathrm{O}}, \mathrm{Au}(\mathrm{HS})_{2}^{-}\right.$; Benning and Seward, 1996; Gibert et al., 1998; Fleet and Knipe, 2000, and references therein), its precipitation in native state requires a reduction from its oxidized complexes. In many vein deposits containing arsenopyrite, gold precipitation occurs later than the formation of arsenopyrite \pm pyrite (Heinrich and Eadington,
1986; Genkin et al., 1998). As already emphasized by Heinrich and Eadington (1986), native gold deposition on grain boundaries and in cracks of preexisting arsenopyrite is likely to be explained by minor redissolution of arsenopyrite according to Eqn. 2 or equivalent, a process that would act as a local redox trap for gold. This hypothesis is confirmed by calculations of $\mathrm{Au}$ solubility in the presence of arsenopyrite. For example, gold concentration calculated in solution in the system FeAsS-Au$\mathrm{H}_{2} \mathrm{O} \pm \mathrm{HCl}$ at 250 to $350^{\circ} \mathrm{C}$ and 500 bar and assuming a congruent FeAsS dissolution (e.g., Eqn. 2) was found to range between 0.1 and $1 \mathrm{ppb}$. This is an order of magnitude lower than the corresponding $\mathrm{Au}$ concentrations calculated assuming equilibrium with pyrite-pyrrhotite ( \pm magnetite), which are believed to be the most common $\mathrm{H}_{2}-$ and $\mathrm{H}_{2} \mathrm{~S}$-buffering assemblages in $\mathrm{Au}$ ore-forming fluids (Gibert et al., 1998). Our predictions are also in agreement with the selective reduction of $\mathrm{Au}^{3+}$ to $\mathrm{Au}^{\mathrm{O}}$ on the surface of arsenopyrite demonstrated experimentally in Au-aqueous solutions at ambient temperature (Möller and Kersten, 1994; Maddox et al., 1998) and with Au chemosorption on As-rich surfaces of arsenopyrite and pyrite (Fleet and Mumin, 1997). Thus, among different processes leading to Au precipitation in crustal fluids, the highly reducing conditions (in comparison to the bulk fluid) created by local dissolution of arsenopyrite can be an effective mechanism of extracting gold from hydrothermal solutions.

\section{CONCLUDING REMARKS}

The stability and solubility of arsenopyrite (FeAsS) were studied at temperatures from 300 to $450^{\circ} \mathrm{C}$ and pressures to 1000 bar in aqueous solutions buffered or not with $\mathrm{H}_{2}$ and/or $\mathrm{H}_{2} \mathrm{~S}$ and as a function of $\mathrm{HCl}$ concentration. Arsenic concentrations measured in equilibrium with $\mathrm{FeAsS}$ in aqueous solution with $\mathrm{H}_{2}$ and $\mathrm{H}_{2} \mathrm{~S}$ fugacities buffered by the pyrite-pyrrhotite-magnetite assemblage were combined with the available thermodynamic data on $\mathrm{As}(\mathrm{OH})_{3}^{\mathrm{O}}(\mathrm{aq})$ (Pokrovski et al., 1996) and heat capacity and entropy data for FeAsS (Pashinkin et al., 1989) to generate a new set of arsenopyrite thermodynamic parameters from 25 to $600^{\circ} \mathrm{C}$. The results obtained imply a higher stability of FeAsS in aqueous environments than was widely assumed until now. Arsenopyrite stability and solidphase equilibria in the system Fe-As-S predicted using these properties are in good agreement with As solution concentrations and mineral parageneses found in FeAsS dissolution experiments carried out without PyPoMt buffering as a function of $\mathrm{pH}$ and with excess $\mathrm{H}_{2}$ or $\mathrm{H}_{2} \mathrm{~S}$.

Calculations of As contents in natural hydrothermal fluids performed using the new thermodynamic properties of FeAsS and assuming a chemical equilibrium between arsenopyrite (or As-pyrite) and solution are in agreement with As concentrations measured in fluid inclusions in quartz from vein-style $\mathrm{Sn}$ and $\mathrm{W}$ deposits and in modern high-temperature hydrothermal reservoirs. It follows that arsenopyrite and As-bearing pyrite are likely to control arsenic behavior in relatively dense hightemperature fluids $\left(150 \leq T \leq 450^{\circ} \mathrm{C}\right)$ in which $\mathrm{As}(\mathrm{OH})_{3}^{0}(\mathrm{aq})$ is the dominant arsenic species. The close association of gold with these minerals in meso- and epithermal deposits could possibly be explained by the dissolution of FeAsS, a process that locally creates more reducing conditions than in the bulk fluid and thus leads to gold reduction and precipitation. 
Accurate knowledge of the stability and thermodynamic properties of aqueous and mineral species in the system Fe-As$\mathrm{S}-\mathrm{H}_{2} \mathrm{O}$ is necessary to quantitatively predict fluid-rock interactions and ore formation in hot hydrothermal environments. Thermodynamic predictions carried out in this study would be better constrained when in situ measurements of redox potential and accurate high-temperature $\left(>350\right.$ to $\left.400^{\circ} \mathrm{C}\right)$ thermodynamic properties of the main aqueous arsenic species $\mathrm{As}(\mathrm{OH})_{3}^{\mathrm{O}}(\mathrm{aq})$ become available. In situ measurements of $\mathrm{As}(\mathrm{OH})_{3}^{\mathrm{O}}(\mathrm{aq})$ molal volume and heat capacity near the critical point of water are now in progress. Such data combined with solubility measurements at carefully controlled $f_{\mathrm{H}_{2} \mathrm{~S}}$ and redox parameters of other arsenide minerals, such as $\mathrm{FeAs}_{2}$, CoAsS, and $\mathrm{NiAs}_{3}$, would allow an improved quantification of their stabilities and formation conditions in hydrothermal environments.

Acknowledgments-This research was supported by the French Ministère de l'Enseignement Supérieur et de la Recherche (awarding a grant "Coup de pouce for young scientist" to Gleb Pokrovski) and by a grant from CNRS/INSU ("Equipements mi-lourds"). We are grateful to O. Rouer, J-M. Bény, and M. Genty for their technical assistance during Raman spectroscopic, EMP, and SEM analyses, respectively, and to L. Peilleron, D. Bellenoue, and A. Lefevre for their help in setting up the experimental equipment. We thank I. Pekov, A. Zotov, J. Jedwab, K. Kouzmanov, and O. Rouer for generously providing us with mineral samples and $\mathrm{M}$. Pichavant and A. Borisova for their assistance during the experiments with the Coretest apparatus. I. Khodakovsky and A. Pashinkin are acknowledged for supplying some thermochemical data and helpful discussions about arsenopyrite thermodynamics. We thank D. Moncgrieff for correcting the manuscript English. The constructive comments of the associate editor, J. D. Rimstidt; reviewers C. Heinrich and F. Gibert; and an anonymous reviewer greatly improved the presentation and clarity of this paper.

Associate editor: J. D. Rimstidt

\section{REFERENCES}

Akinfiev N. N., Zotov A. V., and Nikonorov A. P. (1992) Thermodynamic analysis of equilibria in the system As(III)-S(II)-O-H. Geochim. Intl. 29, (12) 109-121.

Arehart G. B., Chryssoulis S. L., and Kesler S. E. (1993) Gold and arsenic in iron sulfides from sediment-hosted disseminated gold deposits: Implication for depositional processes. Econ. Geol. 88, 171-185.

Audédat A., Günther D., and Heinrich C. A. (1998) Formation of a magmatic-hydrothermal ore deposit: Insights with LA-ICP-MS analysis of fluid inclusions. Science 279, 2091-2094.

Audédat A., Günther D., and Heinrich C. A. (2000) Causes for largescale metal zonation around mineralized plutons: Fluid inclusion LA-ICP-MS evidence from the Mole Granite, Australia. Econ. Geol. 95, 1563-1581.

Ballantine J. M. and Moore J. N. (1988) Arsenic geochemistry in geothermal systems. Geochim. Cosmochim. Acta 52, 475-483.

Barton P. B. (1969) Thermodynamic study of the system Fe-As-S. Geochim. Cosmochim. Acta 33, 841-857.

Barton P. B. (1970) Sulfide petrology. Mineral. Soc. Am. Spec. Pap. 3, 187-198.

Benning L. G. and Seward T. M. (1996) Hydrosulphide complexing of $\mathrm{Au}(\mathrm{I})$ in hydrothermal solutions from $150-400^{\circ} \mathrm{C}$ and $500-1500$ bar. Geochim. Cosmochim. Acta 60, 1849-1871.

Boyle R. W. (1979) The geochemistry of gold and its deposits. Geol. Surv. Can. Bull. 280, 1-584.

Cabri L. J., Chryssoulis S. L., De Villiers J. P. R., Laflamme J. H. G., and Buseck P. R. (1989) The nature of "invisible" gold in arsenopyrite. Can. Mineral. 27, 353-362.
Cabri L. J., Newville M., Gordon R. A., Crozier E. D., Sutton S. R., McMahon G., and Jiang D-T. (2000) Chemical speciation of gold in arsenopyrite. Can. Mineral. 38, 1265-1281.

Cathelineau M., Boiron M-C., Holliger P., Marion P., and Denis M. (1989) Gold in arsenopyrites: Crystal chemistry, location and state, physical and chemical conditions of deposition. Econ. Geol. Monograph. 6, 328-341.

Charlot G. (1966) Les Méthodes de la Chimie Analytique: Analyse Quantitative Minerale. Masson, Paris.

Clark L. A. (1960) The Fe-As-S system: Phase relations and applications. Econ. Geol. 55, Part I: 1345-1381, Part II: 1631-1652.

Cook N. J. and Chryssoulis S. L. (1990) Concentration of "invisible" gold in the common sulfides. Can. Mineral. 28, 1-16.

Eary L. E. (1992) The solubility of amorphous $\mathrm{As}_{2} \mathrm{~S}_{3}$ from 25 to $90^{\circ} \mathrm{C}$. Geochim. Cosmochim. Acta 56, 2267-2280.

Fleet M. E. and Knipe S. W. (2000) Solubility of native gold in H-O-S fluids at $100-400^{\circ} \mathrm{C}$ and high $\mathrm{H}_{2} \mathrm{~S}$ content. J. Solution Chem. 29, 1143-1157.

Fleet M. E. and Mumin A. H. (1997) Gold-bearing arsenian pyrite and marcasite and arsenopyrite from Carlin Trend gold deposits and laboratory synthesis. Am. Mineral. 82, 182-193.

Fleet M. E., MacLean P. J., and Barbier J. (1989) Oscillatory-zoned As-bearing pyrite from strata-bound and stratiform gold deposits: An indicator of ore fluid evolution. In The Geology of Gold Deposits: The Perspectives in 1988, 6 (eds. R. R. Keays, W. R. H. Ramsay, and D. I. Groves), 356-362. Econ. Geol. Monogr.

Fleet M. E., Chryssoulis S. L., MacLean P. J., Davidson R., and Weisener C. G. (1993) Arsenian pyrite from gold deposits: Au and As distribution investigated by SIMS and EPM, and color staining and surface oxidation by XPS and LIMS. Can. Mineral. 31, 1-17.

Fuess H., Kratz T., Töpel-Schadt J., and Miehe G. (1987) Crystal structure refinement and electron microscopy of arsenopyrite. Zeit. Kristall. 179, 335-346.

Genkin A. D., Bortnikov N. S., Cabri L. J., Wagner F. E., Stanley C. J., Safonov Y. G., McMahon G., Friedl J., Kerzin A. L., and Gamyanin G. N. (1998) A multidisciplinary study of invisible gold in arsenopyrite from four mesothermal gold deposits in Siberia, Russian Federation. Econ. Geol. 93, 463-487.

Gibert F., Pascal M. L., and Pichavant M. (1998) Gold solubility and speciation in hydrothermal solutions: Experimental study of the stability of hydrosulfide complex of gold $\left(\mathrm{AuHS}^{0}\right)$ at 350 to $450^{\circ} \mathrm{C}$ and 500 bars. Geochim. Cosmochim. Acta 62, 2931-2947.

Gonzalez-Alvarez D., Gronvold F., Falk B., Westrum E. F., Blachnik R., and Kudermann G. (1989) FeAs: Heat capacity, enthalpy increments, other thermodynamic properties from 5 to $1350 \mathrm{~K}$, and magnetic transition. J. Chem. Thermodynamics 21, 363-373.

Gout R., Pokrovski G. S., Schott J., and Zwick A. (1997) Raman spectroscopy study of arsenic speciation in aqueous solution to $275^{\circ}$ C. J. Raman Spect. 28, 725-730.

Heinrich C. A. (1990) The chemistry of hydrothermal tin (-tungsten) ore deposits. Econ. Geol. 85, 457-481.

Heinrich C. A. and Eadington P. J. (1986) Thermodynamic predictions of the hydrothermal chemistry of arsenic and their significance for the paragenetic sequence of some cassiterite-arsenopyrite-base metal sulfide deposits. Econ. Geol. 81, 511-529.

Heinrich C. A., Ryan C. G., and Ternagh P. M. (1992) Segregation of ore metals between brine and vapor: A fluid inclusion study using PIXE microanalysis. Econ. Geol. 87, 1566-1583.

Heinrich C. A., Günther D., Audédat A., Ulrich T., and Frischknecht R. (1999) Metal fractionation between magmatic brine and vapour, and the link between porphyry-style and epithermal $\mathrm{Cu}-\mathrm{Au}$ deposits. Geology 27, 755-758.

Helgeson H. C. and Kirkham D. H. (1974) Theoretical prediction of the thermodynamic behavior of aqueous electrolytes at high pressures and temperatures: II. Debye-Hückel parameters for activity coefficients and relative partial molal properties. Am. J. Sci. 274, 11991261.

Helgeson H. C., Kirkham D. H., and Flowers G. C. (1981) Theoretical prediction of the thermodynamic behavior of aqueous electrolytes at high pressures and temperatures: IV. Calculation of activity coefficients, osmotic coefficients, and apparent molal and standard and relative partial molal properties to $600^{\circ} \mathrm{C}$ and $5 \mathrm{kbar}$. Am. J. Sci. 281, $1249-1516$. 
Helz G. R., Tossel J. A., Charnock J. M., Pattrick R. A. D., Vaughan D. J., and Garner C. D. (1995) Oligomerization in As(III) sulfide solutions: Theoretical and spectroscopic evidence. Geochim. Cosmochim. Acta 59, 4591-4604.

Hemingway B. S. (1990) Thermodynamic properties for busenite, NiO, magnetite, $\mathrm{Fe}_{3} \mathrm{O}_{4}$, and hematite, $\mathrm{Fe}_{2} \mathrm{O}_{3}$, with comments on selected oxygen buffer reactions. Am. Mineral. 75, 781-790.

Johan Z., Marcoux E., and Bonnemaison M. (1989) Arsénopyrite aurifère: Mode de substitution de Au dans la structure de FeAsS. Comptes Rendus Acad. Sci. Paris 308, 185-191.

Johnson J. W., Oelkers E. H., and Helgeson H. C. (1992) SUPCRT92: A software package for calculating the standard molal thermodynamic properties of minerals, gases, aqueous species, and reactions from 1 to 5000 bar and 0 to $1000^{\circ}$ C. Comp. Geosci. 18, 899-947.

Kerr L. C., Craw D., and Youngson J. H. (1999) Arsenopyrite compositional variation over variable temperatures of mineralization, Otago Schist, New Zealand. Econ. Geol. 94, 123-128.

Kestin J., Sengers J. V., Kamgar-Parsi B., and Levelt Sengers J. M. H. (1984) Thermophysical properties of fluid $\mathrm{H}_{2}$ O. J. Phys. Chem. Ref. Data. 13, 175-183.

Kishima N. (1989) A thermodynamic study on the pyrite-pyrrhotitemagnetite-water system at $300-500^{\circ} \mathrm{C}$ with relevance to the fugacity/concentration quotient of aqueous $\mathrm{H}_{2} \mathrm{~S}$. Geochim. Cosmochim. Acta 53, 2143-2155.

Kolonin G. R., Pal'yanova G. A., and Shironosova G. P. (1989) Arsenopyrite stability and solubility in hydrothermal solutions. Geochem. Intl. 26, (1) 66-78.

Korsakova N. V., Kokina T. A., Sushchevskaya T. M., and Varshal G. M. (1991) Potentiometric determination of sulfide sulfur in solutions in inclusions. Geochem. Intl. 28, (8) 42-51.

Kretschmar U. and Scott S. D. (1976) Phase relations involving arsenopyrite in the system Fe-As-S and their application. Can. Mineral. 14, 364-386.

Maddox L. M., Bancroft G. M., Scaini M. J., and Lorimer J. W. (1998) Invisible gold: Comparison of Au deposition on pyrite and arsenopyrite. Am. Mineral. 83, 1240-1245.

Maier C. G. and Kelley K. K. (1932) An equation for the representation of high-temperature heat-content data. J. Am. Chem. Soc. 54, 32433246.

Mao S. H. (1991) Occurrence and distribution of invisible gold in a Carlin-type gold deposit in China. Am. Mineral. 76, 1964-1972.

Mironova G. D., Zotov A. V., and Gulko N. I. (1990) The solubility of orpiment in sulfide solutions at $25-150^{\circ} \mathrm{C}$ and the stability of arsenic sulfide complexes. Geochem. Intl. 27, (12) 61-73.

Möller P. and Kersten G. (1994) Electrochemical accumulation of visible gold on pyrite and arsenopyrite surfaces. Mineral. Deposita 29, 404-413.

Morimoto N. and Clark L. A. (1961) Arsenopyrite crystal-chemical relations. Am. Mineral. 46, 1448-1469.

Mumin A. H., Fleet M. E., and Chryssouilis S. L. (1994) Gold mineralization in As-rich mesothermal gold ores of the Bogosu-Prestea mining district of the Ashanti Gold Belt, Ghana: Remobilization of “invisible" gold. Mineral. Deposita 29, 445-460.

Naumov G. B., Ryzhenko B. N., and Khodakovsky I. L. (1974) Handbook of Thermodynamic Data. U.S. Geological Survey, Reston, VA.

Pal'yanova G. A. and Kolonin G. R. (1992) Arsenopyrite-bearing mineral assemblages as indicators of conditions of hydrothermal mineralization. Geochem. Intl. 29, (5) 120-131.

Pashinkin A. S., Fedorov V. A., Zviadadze G. N., Malkova A. S., Izergin A. P., Izergin A. A., Generalova S. A., Dzaparidze O. I., and Gelovani L. A. (1979) Dissociation pressure of arsenopyrite and investigation of the system Fe-As-S. Zh. Prikl. Khim. 52, 1085-1091 (in Russian).

Pashinkin A. S., Muratova V. A., Antukhov A. M., and Moiseyev N. V. (1989) Heat capacity and thermodynamic functions of arsenopyrite. Neorg. Mater. 23, 221-224. In Russian.

Pashinkin A. S., Muratova V. A., Moiseyev N. V., and Bazhenov J. V. (1991) Heat capacity and thermodynamic functions of iron diarsenide in the temperature range 5 to $300 \mathrm{~K}$. J. Chem. Thermodynamics 23, 827-830.

Plyasunova N. V. and Ivanov I. P. (1991) The concentration of sulfur in solution in equilibrium with the pyrite-magnetite-hematite and pyrite-pyrrhotite-magnetite buffer assemblages at $350-500^{\circ} \mathrm{C}$ and 1 kbar. Geochem. Intl. 28, (8) 52-60.

Pokrovski G. S. (1996) Experimental Study of the Behavior of Germanium, Silicon and Arsenic, and of Aluminum-Silica Complexing in Natural Solutions. Ph.D. thesis, Paul-Sabatier University, Toulouse, France (in French).

Pokrovski G. S., Gout R., Zotov A., Schott J., and Harrichoury J. C. (1996) Thermodynamic properties and stoichiometry of the arsenic(III) hydroxide complexes at hydrothermal conditions. Geochim. Cosmochim. Acta 60, 737-749.

Pokrovski G. S., Roux J., and Zakirov I. V. (2000) Arsenic speciation and the stability of arsenopyrite (FeAsS) in supercritical fluids and hydrothermal steams. In Steam, Water, and Hydrothermal Systems: Physics and Chemistry Meeting for the Needs of Industry (eds. P. R. Tremaine, P. G. Hill, D. E. Irish, and P. V. Balakrishnan), pp. 686-693. NRC Press, Ottawa, Canada.

Pokrovski G. S., Zakirov I. V., Roux J., Testemale D., Hazemann J. L., Bychkov A. Y., Golikova G. V. (submitted) Experimental study of arsenic speciation in vapor phase to $500^{\circ} \mathrm{C}$ : Implications for $\mathrm{As}$ transport and fractionation in low-density crustal fluids and volcanic gases. Geochim. Cosmochim. Acta.

Robie R. A., Hemingway B. S., Fisher J. R.(1978) Thermodynamic properties of minerals and related substances at $298.15 \mathrm{~K}$ and $1 \mathrm{bar}$ $\left(10^{5}\right.$ pascals) pressure and at higher temperatures. Bull. Geol. Survey 1452, $1-456$.

Scott D. S. (1975) Hydrothermal synthesis of refractory sulfide minerals. Fortschr. Mineral. 52, 185-195.

Scott D. S. (1983) Chemical behavior of sphalerite and arsenopyrite in hydrothermal and metamorphic environments. Mineral. Mag. 47, 427-435.

Sergeeva E. I. and Khodakovsky I. L. (1969) Physical chemical conditions of native arsenic formation in hydrothermal deposits. Geokhimia 7, 846-858 (in Russian).

Sharp Z. D., Essene E. J., and Kelly W. C. (1985) A re-examination of the arsenopyrite geothermometer: Pressure considerations and applications to natural assemblages. Can. Mineral. 23, 517-534.

Shock E. L., Sassani D. C., Willis M., and Sverjensky D. A. (1997) Inorganic species in geological fluids: Correlations among standard molal thermodynamic properties of aqueous ions and hydroxide complexes. Geochim. Cosmochim. Acta 61, 907-950.

Shvarov Y. V., and Bastrakov E. (1999) HCh: a software package for geochemical equilibrium modelling. User's Guide. Australian Geological Survey Organization, record 1999/25.

Simon G., Huang H., Penner-Hahn J. E., Kesler S. E., and Kao L-S. (1999) Oxidation state of gold and arsenic in gold-bearing arsenian pyrite. Am. Mineral. 84, 1071-1079.

Spycher N. F. and Reed M. H. (1989a) As(III) and Sb(III) sulfide complexes: An evaluation of stoichiometry and stability from existing experimental data. Geochim. Cosmochim. Acta 53, 2185-2194.

Spycher N. F. and Reed M. H. (1989b) Evolution of a Broadlands-type epithermal ore fluid along alternative P-T paths: Implications for the transport and deposition of base, precious, and volatile metals. Econ. Geol. 84, 328-359.

Stolyarova T. A. (1977) The enthalpies of formation of iron arsenides. Geokhimia 7, 1095-1098 (in Russian).

Strathdee B. A. and Pidgeon L. M. (1961) Thermal decomposition and vapor pressure measurements of arsenopyrite and arsenical ore. Can. Min. Met. Bull. 54, 883-887.

Sushchevskaya T. M., Kokina T. A., Bannykh L. N., Sedykh E. M., and Knyazeva S. N. (1993) Arsenic in tin-bearing hydrothermal solutions indicated by atomic absorption spectroscopy on water leachates from inclusions in quartz. Geochem. Intl. 30, (2) 89-95.

Sushchevskaya T. M., Durisova J., Yerokhin A. M., Knyazeva S. N., Kokina T. A., Kalinichenko A. M., Lokhov K. I., and Prisyagina N. I. (1996) A study of the chemical characteristics of the medium of the cassiterite-quartz-type mineralization based on fluid inclusions in minerals. Geochem. Intl. 33, (3) 1-22.

Sverjensky D. A., Shock E. L., and Helgeson H. C. (1997) Prediction of the thermodynamic properties of aqueous metal complexes to $1000^{\circ} \mathrm{C}$ and $5 \mathrm{~kb}$. Geochim. Cosmochim. Acta 61, 1359-1412.

Tagirov B. R., Zotov A. V., and Akinfiev N. N. (1997) Experimental study of the dissociation of $\mathrm{HCl}$ from 350 to $500^{\circ} \mathrm{C}$ and from 500 to 
2500 bar. Thermodynamic properties of $\mathrm{HCl}^{0}(\mathrm{aq})$. Geochim. Cosmochim. Acta 61, 4267-4280.

Tanger J. C. and Helgeson H. C. (1988) Calculation of the thermodynamic and transport properties of aqueous species at high pressures and temperatures: Revised equations of state for the standard partial molal properties of ions and electrolytes. Am. J. Sci. 288, 19-98.

Tossel J. A., Vaughan D. J., and Burdett J. K. (1981) Pyrite, marcasite, and arsenopyrite minerals: Crystal chemical and structural principles. Phys. Chem. Minerals 7, 177-184.

Toulmin P. and Barton Jr. P. B. (1964) A thermodynamic study of pyrite and pyrrhotite. Geochim. Cosmochim. Acta 28, 641-671.

Wagman D. D., Evans W. H., Parker V. B., Schumm R. H., Halow I., Bailey S. M., Churney K. L., Nuttall R. L. (1982) The NBS tables of chemical thermodynamic properties. Selected values for inorganic and $\mathrm{C}_{1}$ and $\mathrm{C}_{2}$ organic substances in SI units. J. Phys. Chem. Ref. Data 11(Suppl. 2), p. 180

Webster J. G. (1990) The solubility of $\mathrm{As}_{2} \mathrm{~S}_{3}$ and speciation of As in dilute and sulfide-bearing fluids at 25 and $90^{\circ} \mathrm{C}$. Geochim. Cosmochim. Acta 54, 1009-1017.

Wones B. R. (1981) Mafic silicates as indicators of intensive variables in granitic magmas. Mining Geol. 31, 191-212.

Wu X. and Delbove F. (1989) Hydrothermal synthesis of gold-bearing arsenopyrite. Econ. Geol. 84, 2029-2032.

Yund R. A. and Hall H. T. (1969) Hexagonal and monoclinic pyrrhotites. Econ. Geol. 64, 420-423.

Zviadadze G. N. and Rtskhiladze V. G. (1964) Thermodynamics of the dissociation of arsenopyrite. Soobsch. Acad. Nauk Gruz. SSR 33, 175-181 (in Russian). 